\title{
Chapter 7 Did Humans Cause the Late Pleistocene-Early Holocene Mammalian Extinctions in South America in a Context of Shrinking Open Areas?
}

\author{
Alberto L. Cione( ()$_{)}$, Eduardo P. Tonni, and Leopoldo Soibelzon
}

Keywords South America • mammals • extinction • pseudo extinction $\bullet$ human impacts

\section{Introduction}

The last important - and possibly the most spectacular - turnover in South American mammal history occurred around the Pleistocene-Holocene boundary, when $100 \%$ of megamammal species and about $80 \%$ of large mammal species became extinct. In this paper, we consider as "megamammals" those with body mass over $1,000 \mathrm{~kg}$, and "large mammals" those over $44 \mathrm{~kg}$ (Tables 7.1 and 7.2). With the exception of a few smaller mammals, no other animal or plant disappeared. Consequently, this extinction event was distinct from mass extinctions (see comments in Cione et al., 2003).

South American communities had included at least some megamammals since the latest Paleogene, but gigantism in mammals markedly emerged during the Ensenadan age (early Pleistocene; Fig. 7.1) when many large mammal genera first appeared (Ameghino, 1889; Pascual et al., 1965; Cione and Tonni, 2005). Most genera, with different species, survived during the late Pleistocene when the remarkable figure of 37 megamammal species can be documented (Table 7.1). Many appear to have persisted in the early Holocene. However, none is living today. Moreover, presently there are no megammals in the Americas, Europe, and Australia. In Asia today there are only two megamammals and in Africa four megamammal species and the giraffe, close to a ton in body mass. The largest terrestrial mammal in the Neotropics is the tapir Tapirus bairdii, some individuals of which slightly surpass $300 \mathrm{~kg}$ (Nowak and Paradiso, 1983).

The large mammal extinction of the latest Cenozoic occurred on different continents and islands at different times

\footnotetext{
Alberto L. Cione $(\varpi)$

División Paleontología de Vertebrados, Facultad de

Ciencias Naturales y Museo Paseo del Bosque,

1900 La Plata, rgentina

e-mail: acione@museo.fcnym.unlp.edu.ar,eptonni@museo.fcnym.unlp.

edu.ar, lsoibelzon@museo.fcnym.unlp.edu.ar.
}

(Steadman et al., 2005). For explaining these extinctionsseveral hypotheses have been proposed, most related to cold climate, disease, or human activities. We agree with Barnosky et al. (2004) in that the accumulated evidence suggests it is time to move beyond casting the Pleistocene extinction debate as a dichotomy of climate versus humans. In this context, we have proposed what we call the Broken Zig-Zag hypothesis (Cione et al., 2003). During most of the middle and late Pleistocene, dry and cold climate caused open areas to predominate in South America. Nearly all megamammals and large mammals that became extinct were adapted to this kind of environment. The periodic though relatively short interglacial increases in temperature and humidity led to dramatic shrinking of open areas and extreme reduction of the mammalian biomass (albeit not of species richness) adapted to open habitats. However, during the longer glacial periods, open-area mammal populations recovered. This alternation of low and high biomass of mammals from open and closed areas is what we refer to as the Zig-Zag. Remarkably, the extinction rate of large mammals and megamammals during more than a half million years was not high, until rising abruptly during the latest Pleistocene.

In this paper, (1) we analyze the biostratigraphic and chronologic pattern of the large continental mammals of South America during the late Pleistocene-earliest Holocene with new evidence, (2) discuss why megamammals and large mammals were more liable to become extinct than those that survived, (3) discuss the timing of human entry into South America, and (4) examine the possible role of humans in this extinction.

\section{The Broken Zig-Zag Hypothesis}

We have proposed that megamammal and large mammal extinction in South America during the late Pleistoceneearliest Holocene was caused by human foragers (Cione et al., 2003). However, we believe that this event would have been favoured by a particular circumstance: total biomass (not diversity) and distribution of open-area-adapted mammals began to be extremely reduced in response to the periodic shrinking of this kind of environments (the Zig-Zag) 
Table 7.1 Mammal taxa present in putative Lujanian (sensu Cione and Tonni, 1999) beds in South America and that became extinct (modified from Cione et al., 2003). Asterisks indicate taxa that occur in archeological sites

\begin{tabular}{ll}
\hline Megamammals & Large mammals \\
\hline Cuvieronius humboldti $^{*}$ & Antifer niemeyeri \\
Cuvieronius hyodon & Arctotherium bonariense \\
Doedicurus clavicaudatus ${ }^{*}$ & Arctotherium brasiliense \\
Eremotherium carolinense & Arctotherium tarijense \\
Eremotherium laurillardi & Brasiliochoerus stenocephalus \\
Eremotherium mirabile & Equus (A.) andium \\
Eremotherium rusconii & Equus (A.) insulatus \\
Glossotherium (Oreomylodon) & Equus (A.) lasallei
\end{tabular}
wagneri

Glossotherium lettsomi

Glossotherium (Pseudolestodon) myloides

Glossotherium robustum ${ }^{*}$

Glossotherium tropicorum

Glyptodon clavipes

Glyptodon perforatus

Glyptodon reticulatus

Glyptotherium cf. cylindricum*

Hemiauchenia paradoxa *

Lestodon armatus

Lestodon trigonidens

Macrauchenia patachonica*

Megalonyx sp.

Megatherium americanum ${ }^{*}$

Megatherium medinae

Mixotoxodon larensis

Mylodon darwinii

Mylodon listai*

Neothoracophorus depressus

Panochthus frenzelianus

Panochthus morenoi

Panochthus tuberculatus

Plaxhaplous canaliculatus

Stegomastodon platensis

Stegomastodon guayasensis

Stegomastodon waringi

Toxodon burmeisteri

Toxodon platensis ${ }^{*}$

Xenorhinotherium bahiense

\section{Medium sized mammals}

\section{Canis dirus}

Dusicyon avus ${ }^{*}$

Protocyon orcesi

Protocyon troglodytes

Protopithecus brasiliensis

Valgipes deformis

Eutatus seguini

Eutatus punctatus

Glyptotherium sp.

Hippidion principale ${ }^{*}$

Holmesina occidentalis

Holmesina paulacoutoi

Hoplophorus euphractus

Lama gracilis

Morenelaphus lujanensis

Mylodopsis ibseni

Neochoerus aesopy

Neochoerus sirasakae

Neosclerocalyptus paskoensis*

Neuryurus $n$. $s p$.

Nothropus priscus

Nothrotherium roverei

Ocnopus gracilis

Ocnotherium giganteum

Onohippidion saldiasi ${ }^{*}$

Palaeolama niedae

Palaeolama weddelli

Pampatherium humboldti

Pampatherium typum

Paraceros fragilis

Parapanochthus jaguaribensis

Propraopus grandis

Propraopus humboldti

Propraopus magnus

Scelidodon cuvieri

Scelidodon chiliensis

Scelidodon reyesi

Scelidotherium leptocephalum

Smilodon populator

Tapirus cristatellus

Trigonodops lopesi
Table 7.2 Large mammals and megamammals in the Guerrero Member of the Luján Formation and correlative units

Antifer neumeieri Megatherium americanum

Arctotherium bonariense

Arctotherium tarijense

Ctenomys lujanensis

Cuvieronius humboltii

Dusicyon avus

Doedicurus clavicaudatus

Equus (A.) andium

Equus (A.) neogeus

Eremotherium sp.

Eulamaops paralellus

Eutatus seguini

Eutatus punctatus

Glossotherium lettsomi

Glossotherium myloides

Glossotherium robustum

Glyptodon clavipes

Glyptodon perforatus

Glyptodon reticulatus

Glyptotherium cylindricum

Hemiauchenia paradoxa

Megatherium lundi

Megatherium tarijense

Morenelaphus lujanensis

Mylodon darwinii

Mylodon listai

Neochoerus aesopy

Neosclerocalyptus paskoensis

Neothoracophorus depressus

Neuryurus n. sp.

Onohippidium salidiasi

Palaeolama sp.

Pampatherium typum

Panochthus morenoi

Panochthus tuberculatus

Paraceros fragilis

Hippidion principale

Holmesina sp.

Lama gracilis

Lestodon armatus

Lestodon trigonidens

Macrauchenia patachonica

Plaxhaplous canaliculatus

Propraopus grandis

Scelidodon sp.

Scelidotherium leptocephalum

Smilodon populator

Stegomastodon platensis

Stegomastodon waringi

Toxodon burmeisteri

Toxodon platensis which was provoked by the last (present) interglacial's periodic rising temperature and humidity. Humans certainly did not exterminate all the extinct taxa (e.g., the large carnivores), but killed off many and provoked changes that occasioned the disappearance of the remaining ones (see also Kay, 2002).

\section{The Zig-Zag}

Studies based on geochemical proxies in glacial ice cores from Greenland, Antarctica, and South America show that temperatures strongly fluctuated during at least the last $400 \mathrm{ka}$ and that the present interglacial is not substantially different from the earlier ones, of which there were over 20 during the middle-late Pleistocene (Fig. 7.1; McCulloch et al., 2000; Blunier and Brook, 2001; Steig, 2006). The periodic changes in Pleistocene climate provoked dramatic modifications in the distribution and biomass of the biota in South America and other continents. We use the expression Zig-Zag to stress the periodicity of biotic trends.

To determine the impact of changes, we evaluated the possible modification of vegetation physiognomy. In modern 
Fig. 7.1 Chronological chart of the middle Pleistocene-Recent in southern South America depicting mammal zones and South American ages (modified from Cione and Tonni, 2005) and the climatic oscilations represented by (1) ${ }^{18} \mathrm{O}$ of Vostok, Antarctica (Petit et al., 1999) and (2) Dronning Maud Land, Antartica (Steig, 2006)

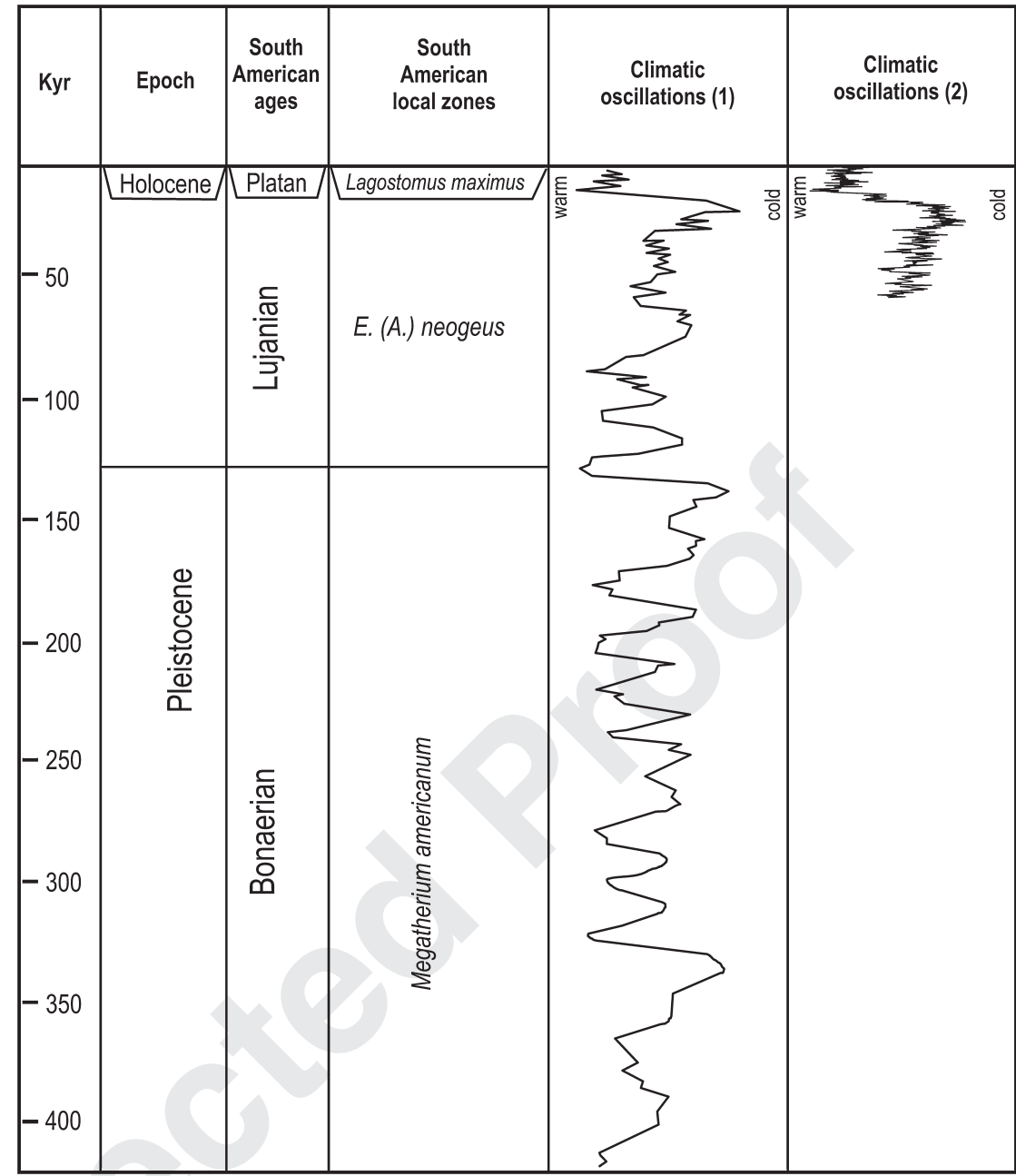

South America, $18 \%$ of the land is characterized as open areas, while medium vegetated areas make up $15 \%$ and closed areas make up 67\% (Cione et al., 2003). In contrast, by using the reconstruction of South America during the LGM, we calculated that open areas would have encompassed $31 \%$ of the territory, medium areas 54\%, and closed areas 15\% (Cione et al., 2003). Simberloff (1986 fide Raup, 1992: 136) had calculated that areas of wet forests were reduced by $84 \%$ during this time. We understand that the most difficult definition is that of the "medium vegetated areas." In this term, cerrados, chaco, monte, and other relatively closed areas are included along with some more open areas (see Clapperton, 1993a, his Fig. 23.10). For this, we consider that the geological, floristic, and faunistic evidence from the present densely vegetated areas suggests that open areas were even larger than depicted by Clapperton (1993a, his Fig. 23.10). Similar results were obtained by Vivo and Carmignotto (2004) based on the distribution of plant formations (Fig. 7.2; see also Johnson, 2002).
We commented above that during the late Pleistocene the mammal diversity was higher especially because many different species of large and megamammals were thriving in the Pampean area and the rest of South America. However, although the taxonomic diversity was elevated, the number of individuals per species and the total biomass in each location probably was not high because most of the South American glacial ecosystems should not have been very productive. During the glacial times, while climate was colder and drier in extraglacial areas, open areas expanded and animals and plants that were adapted to these environments augmented their distribution and biomass (Tonni and Cione, 1997; Tonni et al., 1999a; Cione et al., 2003). During the shorter interglacial periods, when temperature was higher than present (Thompson, 2000; Blunier and Brook, 2001; Vivo and Carmignotto, 2004), an expansion of the forested areas may be expected, and with this an increase in the biomass of forest dwelling animals, including those that survived the 

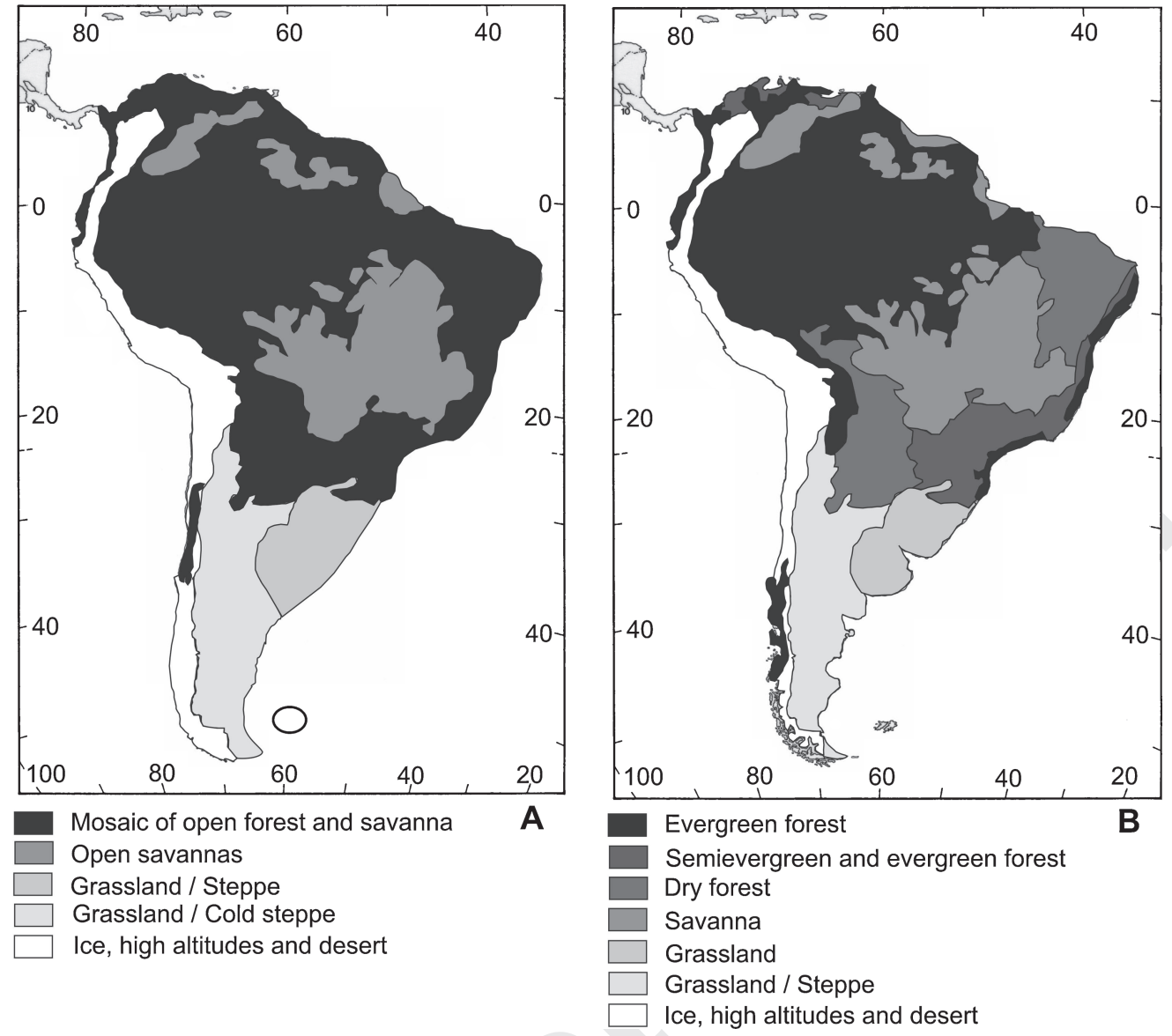

Fig. 7.2 Map depicting plant distribution in South America (modified from Vivo and Carmignotto, 2004). A. Last Glacial Maximum (the emerged shelf is depicted). B. Present day

Pleistocene-Holocene extinction, such as tapirs (Pardiñas et al., 1996; see above).

Remarkably, the fossil record does not suggest that these cyclic environmental changes either produced depletion of niches or caused massive extinction of mammals (Cione et al., 1999; Tonni et al., 1999b; Nabel et al., 2000). In the short interglacial periods, mammals adapted to open areas had not necessarily been starving, but populations were surely remarkably reduced and under ecological stress. Some populations possibly were close to the minimal viable number and many surely became isolated so that genetic flux greatly diminished among them, reducing variability. The persistence of South American mammal species through a prolonged lapse of important environmental changes could be explained according to the Plus Ça Change Model, in which morphological stasis over geological timescales tends to arise not from the stability of physical environments, but from their instability (Sheldon, 1998).

\section{Implications of the Hypothesis to Be Tested}

This hypothesis is supported by the climatic evolution of the continent, the vegetational history, the positive biostratigraphical evidence, the chronology of extinctions, the paleobiogeography of mammals, the adaptation to open environments of those mammals that became extinct which also were probably k-adapted, the selective disappearance of all megamammals and most large mammals, the almost nil extinction of middle sized and small mammals and other vertebrates, the protected environments where the few surviving large mammals live today, and the fact that American mammals did not coevolve with humans. Morever, the only certain new biological or geological event for the middle-late Pleistocene to Holocene that occurred in the time of extinction was the entrance of humans into the continent. 


\subsection{Methods}

Dates given here are mostly uncalibrated (BP: radiocarbon years before present; see below) and some calibrated (cal bp).

Simulations of South America during LGM with a regional climate model coupled with a potential vegetation model produce a quantitative picture of LGM climate and vegetation distributions that is consistent with the geological proxy data. The model indicates a smaller Amazonian rainforest through the glacial time, associated with drier conditions (Cook and Vizy, 2006). For comparison of the general vegetation for the Recent and the Last Glacial Maximum (LGM) we had designed two maps where three arbitrary categories of vegetational structure were used: open, medium, and closely vegetated areas (see Cione et al., 2003; their Figs. 2 and 3). For this chapter we have modified the biome maps of South America (Fig. 7.2) designed by Vivo and Carmignotto (2004) following the data cited in Cione et al. (2003) and some new references mentioned below.

In Colombia, pollen indicates that at $18,000 \mathrm{BP}$ a generally cool and dry environment is reflected in biome assignments of cold mixed forests, cool evergreen forests and cool grassland/ shrub, the latter extending to lower altitudes than presently recorded (Marchant et al., 2004). From 11,150 to 9,100 cal bp, grass savanna dominated the landscape while gallery forest along the drainage system was poorly developed. Water availability was lower than today and the length of the dry season longer. From 9,100 to 7,330 cal bp gallery forest expanded pointing to wetter conditions (Wille et al., 2003).

In São Francisco de Assis in the western Rio Grande do Sul State in southern Brazil, the region was naturally covered by Campos (grassland) throughout the recorded glacial and Holocene period under conditions that were cold and relatively dry, and warm and dry, respectively. Initial expansion of gallery forest after $5,170 \mathrm{cal}$ bp indicates a change to wetter climatic conditions. Maximum extent of gallery forest after $1550 \mathrm{cal}$ bp reflects the wettest recorded period (Behling, 2002; Behling et al., 2002; Behling et al., 2005).

In the Pampean area of Argentina, several paleosols were dated at about 10,000 BP, at the Holocene Climatic Optimum (HCO), and at about 2,000 BP (Tonni et al., 2001, 2003), indicating wetter conditions.

During the LGM, the prominence of hyper-humid vegetation in southern Chile (north Patagonian and Subantarctic forests and parkland) implies sustained, periodic northward migration of the southern westerlies. Significant cooling events (inferred from the expansion of grass-dominated Subantarctic Parkland) occurred between 17,000 and 35,000 BP. At the end of the last glacial, glacial vegetation was abruptly replaced by more temperate Valdivian and Lowland Deciduous Forests at 17,000 BP. A brief climate reversal,

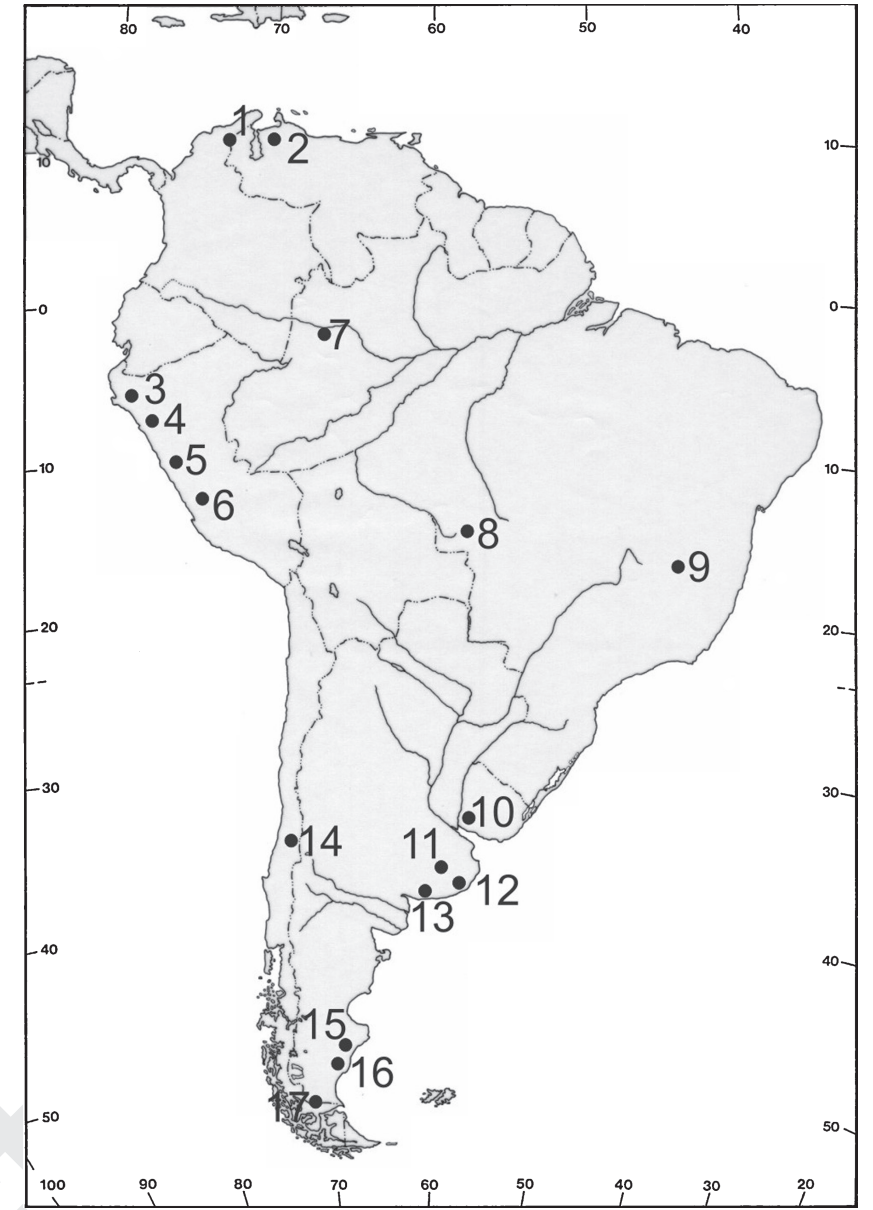

Fig. 7.3 Map of South America depicting most of the sites mentioned in the text. 1. Taima Taima; 2. Muaco; 3. Talara; 4. Cupisnique; 5. Huargo; 6. Ayacucho complex; 7. Río Juruá; 8. Cuiabá; 9. Minas Gerais; 10. Sauce; 11. Tapalqué and Campo Laborde; 13. Cerro La China; 14. Tagua tagua; 11. Arroyo Seco; 15. Los Toldos and Piedra Museo; 16. Las Buitreras; 16. Cueva del Mylodon, Cueva Lago Sofía, Cueva del Medio, Cueva Fell, Pali Aike and Tagua Tagua

centered on 14,000-12,000 BP, interrupted the unidirectional glacial-interglaciation transition. The structure and variability of southern Chilean vegetation and climate closely resemble changes in Antarctic ice core data and in marine surface offshore (Heusser et al., 2006).

\section{Results}

\section{The Pleistocene-Holocene Chronology}

The Pliocene to Recent continental sequence of the southern South America is the most complete for studying the land mammal evolution in the continent for the period. More especifically, the Pampean stratigraphic sequence gave the 
basic framework for the South American late Cenozoic chronological scale (see articles in Tonni and Cione, 1999.; Tonni et al., 2003; Cione and Tonni, 2005).

It is well known since the 19th century that South American mammal faunas underwent marked turnovers in taxonomic composition during the Neogene (Ameghino, 1889; Pascual et al., 1965; Marshall et al., 1984; Tonni et al., 1992; Cione and Tonni, 1995, 2001, 2005; see papers in Tonni and Cione, 1999). The periodic alternation of glacial and interglacial epochs during the middle-late Pleistocene dramatically modified the distribution, composition, and biomass of plant and animal communities in South America as in other regions of the world (Tonni and Fidalgo, 1978; Tonni and Politis, 1980; Graham, 1986; Tonni and Cione, 1997; Pardiñas et al., 1999, 2004; Tonni et al., 1999a; Whitlock and Bartlein, 1997; Haynes, 2002). However, these remarkable changes did not necessarily provoke large extinctions although many new species appeared (Table 7.3).

The global inception of the glacial periods that characterize the middle and late Pleistocene is chronologically related to an important turnover in the South American mammal fauna. It is represented by the boundary between the Mesotherium cristatum and Megatherium americanum biozones in the stratigraphic sections of the Pampean area and in Bolivia (Cione and Tonni, 1999; Cione et al., 1999; MacFadden, 2000; Soibelzon et al., 2005; Cione and Tonni, 2005; Fig 7.1). Both units provide the biostratigraphic basis for the Ensenadan and Bonaerian ages. According to magnetostratigraphic analyses in the Pampean area and Bolivia, the base of the Bonaerian is younger than $0.78 \mathrm{Ma}$, probably ca. 0.5 Ma (Nabel et al., 2000; Cione and Tonni, 2005; Fig. 7.1).

A much smaller turnover has allowed the definition of a biostratigraphic unit in the Pampean area: the Equus (Amerhippus) neogeus biozone (Fig. 7.1). This unit is the basis of the Lujanian age and is dated from about 130,000 to about 7,000 BP. It is characterized by the first record of some mammal taxa and the extinction of other (Pardiñas et al., 1996; Cione and Tonni, 2005). Overlying the Equus (Amerhippus) neogeus biozone is the Lagostomus maximus biozone which constitutes the basis for the Platan age, dated from about 7,000 BP to the 16th century (Fig. 7.1). In this zone, only autochtonous Recent mammals occur, except for the peculiar occurrence of the canid Dusicyon avus during

Table 7.3 Large mammal and megamammal pattern of extinction in the middle Pleistocene to Holocene of South America

\begin{tabular}{llll}
\hline Ages & Ensenadan & Bonaerian & Lujanian \\
\hline Total number of genera & 99 & 75 & 68 \\
Number of extinct genera & 66 & 25 & 43 \\
$\begin{array}{l}\text { Percentage of taxa per total } \\
\quad \text { number of large and mega }\end{array}$ & $67 \%$ & $33 \%$ & $63 \%$ \\
$\begin{array}{l}\text { Duration } \\
\text { Percentage of taxa per duration }\end{array}$ & $55 \%$ & $50 \%$ & $358 \%$ \\
\hline
\end{tabular}

this period (see below). Consequently, the deposition of sediments representing this stage appears to have occurred after the mammal extinctions in South America. In the Lagostomus maximus biozone there are no introduced mammals from the Old World, such as cows, sheep and horses. They occur in the Bos taurus-Ovis aries biozone (Deschamps, 2005), which represent the most recent sediments.

\section{Mammal Diversity during the Middle-Late Pleistocene and Shifts in Distributions}

An outstanding feature of the South American Neogene terrestrial fauna is the presence of a very diverse endemic fauna of gigantic mammals (Ameghino, 1889; Simpson, 1980). The large size of individuals is striking in the Ensenadan, but also continues to be marked in the Bonaerian and Lujanian (Tonni et al., 1992). During the Neogene, until the establishment of the Isthmus of Panama at about $3 \mathrm{Ma}$, these very large mammals were mainly endemic notoungulates, litopterns and xenarthrans. However, mostly during the Pliocene Chapadmalalan and Marplatan ages and the Pleistocene Ensenadan age, many other taxa of Holarctic origin appeared in South America, most of them represented in the first record by endemic genera and species (Cione and Tonni, 1995, 1996). Many of the Holarctic mammals that invaded South America were large (e.g., several felids, ursids, tayassuids, equids, camelids, and cervids), and some others fall in the category of megamammals (gomphotheriids, some ursids).

The Quaternary was a time of extensive evolution among mammals and many of them show adaptations to peculiarly Quaternary environments (Lister, 2004). The South American middle Pleistocene-earliest Holocene (Bonaerian-Lujanian) mammal diversity was significatively higher than that of the middle Holocene to Recent, because it can be presumed that most of the extant mammals (243 genera; 73 genera if we exclude Chiroptera, Rodentia, Lagomorpha, Marsupialia and Insectivora; Nowak and Paradiso, 1983) were present together with those mammals that became extinct in the continent (49 genera, see Table 7.1). In the particular case of the Pampean area, the faunal composition during most of the middle and late Pleistocene was also different from the Recent one because many of the extant mammals occurring there during this interval (except for interglacial times) corresponded to those presently living in arid and/or colder areas to the south and west. At least 24 species of mammals of the Platan or the Recent were documented as inhabiting the Pampean region during at least part of the late Pleistocene (see Cione et al., 1999, 2003; Cione and Tonni, 2005). Except for the absence of the extinct taxa, few "non-analogue" associations (see Graham et al., 1996) were documented in the Bonaerian, Lujanian and Platan from the Pampean area 
(Cione and López Arbarello, 1994; Pardiñas, 1999, 2004). During interglacial times mammals from warmer climates occupied the region, and during the glacial times Patagonian and western taxa occurred there (Pardiñas et al., 1996; Tonni et al., 1999a; Verzi et al., 2002). Actually, there is a very poor record of interglacial times probably because they did not last as long as the glacial intervals, and also because they permitted the development of the kind of soils that foster bone destruction (see Retallack, 1998; Tonni et al., 1999b).

Eighty three extinct species and 46 extinct genera of large mammals and megamammals occur in putative Lujanian beds of South America (from 130,000yr to about 7,000 BP; Table 7.1). There is some stratigraphic inaccuracy in several parts of South America outside Argentina and some records could correspond to beds of Bonaerian age. This means that some of these species might not have been involved in the massive extinction at the end of Lujanian. However, the Lujanian of the Pampean region appears to be characterized primarily by new occurrences, with few extinctions in the top of the Bonaerian (Cione et al., 1999; Cione and Tonni, 2005; Table 7.3), perhaps because some species developed flexible adaptations enabling them to inhabit broad niches and to survive major environmental changes (Lister, 2004), although some evolved fixed adaptations to specialist habits. The large mammals that became extinct at the end of the Pleistocene and beginning of the Holocene were adapted to open environments. Certainly, they could find such environments somewhere in the continent both during the glacial and interglacial periods.

The total mammal generic diversity during Lujanian times could have been as high as 286 genera (49 extinct genera plus 243 Recent genera; Tables 7.1, 7.2). The total large mammal (and megamammal) diversity present during Lujanian times could have been as high as 83 species distributed into 48 genera. Most of the Lujanian taxa that became extinct were large mammals and megamammals.

The well studied Guerrero Member of the Luján Formation in the Pampean area, dated between 21,000 to $10,000 \mathrm{BP}$ (Tonni et al., 2003), and other units in different parts of South America with radiometric dates include at least 52 species distributed into 38 genera (49 large and megamammal species plus 3 smaller mammal species and 35 large and megamammal genera plus 3 smaller mammal genera) (see below).

\section{Was the South American Fauna Declining during the Pleistocene?}

Present evidence indicates that the large-mammal and megamammal fauna was very well diversified at the end of the Pleistocene and did not suffer from any kind of declining trend in previous time intervals. Some South American clades were declining in diversity since the Great American
Biotic Interchange. Litopterns and notoungulates as well as marsupials and large ground birds probably suffered from competition with Holartic taxa. However, xenarthrans continued being much diverse although many new genera of Holarctic origin integrated in the ecosystems, with eight families during the Chapadmalalan to Ensenadan (Cione and Tonni, 1995). Consequently, the fauna was changing but was highly diverse and abundant. There is no evidence that the extinction rate rose during the the glacial periods of the middle and late Pleistocene (see Tonni et al., 1992; Cione and Tonni, 2005). Moreover, the number of megamammals in South America was the largest in the world at this time.

\section{Youngest Records of Extinct Mammals in South America}

The youngest beds where now-extinct mammals (with the exception of Dusicyon avus) have been found in South America are Lujanian in age. Several of these Lujanian localities appear to be early Holocene in age. In North America, there is agreement that the extinctions took place before the beginning of the Holocene, before 10,500 BP (Roy, 2001; Haynes, 2002).

In the river valleys of the South American Pampean region, no extinct mammal has been found in the typical Río Salado Member of the Luján Formation or correlative units, except for the peculiar case of Dusicyon avus (see below). The Lagostomus maximus biozone (and the Platan) begins in the base of this member (Cione and Tonni, 1995). The Río Salado Member is correlated with at least the middle Holocene Las Escobas Formation marine beds which were dated between ca. 6,500 to ca. 2,000 BP. Their deposition coincides with the high sea-level of the Holocene Climatic Optimum (HCO) (Tonni and Fidalgo, 1978; Fidalgo, 1992; Aguirre and Whatley, 1995). Eleven ${ }^{14} \mathrm{C}$ ages based on molluscan shells and total organic matter were obtained from transitional beds between the Guerrero and Río Salado members of the Luján Formation in sections at the Arroyo Tapalqué (central Buenos Aires province; Fig. 7.3) ranging between 9,710 $\pm 110 \mathrm{BP}$ and 8,810 $\pm 140 \mathrm{BP}$ (Figini et al. 1995; Zárate et al. 1995; Cione et al., 2001). In the divides of the Pampean region, no extinct mammal occurs in the uppermost beds of La Postrera Formation (of middle to late Holocene age).

Certainly, the best-known mammal faunas in the South American upper Pleistocene are those found in the Guerrero Member of the Luján Formation, the La Postrera Formation in the Pampean area, and the correlative Dolores Formation of Uruguay (Ameghino, 1889; Prado et al., 1987; Alberdi et al., 1988; Tonni et al., 1992; Martínez, 1997; Cione et al., 1999; Ubilla and Perea, 1999). According to stratigraphic relationships and isotopic dating, the Guerrero Member was deposited 
between 21,000 BP and earliest Holocene (Tonni et al., 2003 and papers cited therein). The localities most accurately dated are Tapalqué and Paso Otero (Tonni et al., 2003; Fig. 7.3).

In addition to those records, in the uppermost Pleistocene beds (dated between 20,000 and 10,000 BP) of several sites in Argentina, Chile, Peru, Uruguay, and Venezuela (Fig. 7.3), the extinct species shown in Table 7.4 were documented. Many of these records were based on dates directly from bones, and dating carried out on the basis of other materials is sufficient to support that timing to the last 20,000 BP.

There are several other records that are doubtful, at best. The identification of Lama cf. owenii is here dismissed (Nami and Nakamura, 1995). The Bonaerian genus Antifer was incorrectly cited for the latest Pleistocene of Buenos Aires and Chile by Aramayo (1997) and Casamiquela (1999). The Mylodon species that is recorded in Patagonia appears to be M. listai and

Table 7.4 Additional records in the uppermost Pleistocene beds (dated between 20,000 and 10,000 BP) of several sites in Argentina, Chile, Peru, Uruguay and Venezuela

\begin{tabular}{|c|c|c|c|}
\hline Taxa & Locality & RCYBP & Reference \\
\hline Mylodon listal & Cueva del Milodón, southern Chile & & Borrero (1997) \\
\hline Megatherium tarijense & Ayacucho complex, Peru & $18,000-15,000$ & Hoffstetler (1986) \\
\hline Megatherlidae indet. & Ayacucho complex, Peru & 12,200 & Mc Neish et al. (1970) \\
\hline Glyptotherium cf. cylindricum & Taima Taima, Venezuela & $12,580 \pm 150$ & Carlini and Zurita (2006) \\
\hline Glyptotherium cf. cylindricum & Muaco, Venezuela & $13,390 \pm 130$ & Carlini and Zurita (2006) \\
\hline Eutatus seguini & $\begin{array}{l}\text { Cerro La China, Cueva Tixi, Buenos } \\
\text { Aires, Argentina }\end{array}$ & & $\begin{array}{l}\text { Flegenheimer and Zárate (1997), } \\
\text { Mazzantl (1997) }\end{array}$ \\
\hline Scelidodon & Talara, Peru & $13,616 \pm 600$ and $14,418 \pm 500$ & $\begin{array}{l}\text { Hoffstetter (1970), Marshall et al. } \\
\quad(1984)\end{array}$ \\
\hline Scelidotheríum & Huargo, Peru & $13,400 \pm 700$ & Hoffstetter (1986) \\
\hline Glossotherium aff. G. lettsoml & $\begin{array}{l}\text { Santa Elina Rockshelter, Cuiaba, } \\
\text { Brazil }\end{array}$ & $23,320 \pm 1000$ and $10120 \pm 60$ & Vialou (2003) \\
\hline Holmesina & Talara, Peru & & $\begin{array}{l}\text { Hoffstetter (1970), Marshall et al. } \\
\text { (1984) }\end{array}$ \\
\hline Eremotherium & Cupisnique, Peru & & Marshall et al. (1984) \\
\hline Lestodon & Sauce, Uruguay & & Arribas et al. (2001) \\
\hline Macrauchenia & Cueva del Mylodon, southern Chile. & & Borrero (1997) \\
\hline Macrauchenia & Taima Taima, Venezuela & & Gruhn and Bryan (1984) \\
\hline Onohippidion saldiasi & $\begin{array}{l}\text { Cueva del Mylodon, Piedra Museo, } \\
\text { Los Toldos, Las Bultreras, Cueva } \\
\text { Lago Sofia, Cueva del Medio, } \\
\text { Fell, Pali Aike, Cerro Sota; } \\
\text { southern Chile and Argentina }\end{array}$ & & $\begin{array}{l}\text { Alberdl and Prado (1992), Miotti } \\
\text { (1993), Borrero, (1997), } \\
\text { Alberdi et al. (2001) }\end{array}$ \\
\hline Onohippidion saldiasi & Huargo, Peru & $13,400 \pm 700$ & Hoffstetter (1986) \\
\hline Lama gracills & $\begin{array}{l}\text { Los Toldos, Piedra Museo, southern } \\
\text { Patagonia }\end{array}$ & & $\begin{array}{l}\text { Miotti and Cattáneo (1997), } \\
\text { Borrero (1997), Borrero et al. } \\
\text { (1998) }\end{array}$ \\
\hline Equus (Amerhippus) neogeus & Tagua Tagua, Chile & & Casamiquela (1999) \\
\hline Equus andium & Ayacucho complex, Peru & & Hoffstetter (1986) \\
\hline Equus & Taima Taima, Venezuela & & Gruhn and Bryan (1984) \\
\hline Hippidion & Taima Taima, Venezuela & & Gruhn and Bryan (1984) \\
\hline Cuvieronius humboldti & Monte Verde, Chile & $11,900 \pm 200$ & Borrero (1997) \\
\hline Stegomastodon & Talara, Perú & & Hoffstetter (1970) \\
\hline Stegomastodon & Taima Taima, Venezuela & & $\begin{array}{l}\text { R. Casamiquela in Gruhn and } \\
\text { Bryan (1984) }\end{array}$ \\
\hline Palaeolama & Cupinisque, Peru & & F. Pujos, personal communication \\
\hline Palaeolama & Monte Verde, Chile & & $\begin{array}{l}\text { Casamiquela and Dillehay (1989 } \\
\text { fide Borrero, 1997: 91) }\end{array}$ \\
\hline Antifer niemeyeri & Tagua Tagua, Chile & & Casamiquela (1999) \\
\hline Dusicyon avus & $\begin{array}{l}\text { Cueva las Buitreras, Cueva Tixi, } \\
\text { Argentina }\end{array}$ & & $\begin{array}{l}\text { Mazzanti (1997), Borrero (1997), } \\
\quad \text { Borrero et al. (1998) }\end{array}$ \\
\hline Smilodon & Cueva Lago Sofia, southern Argentina & $11,210 \pm 50$ & Borrero (1997) \\
\hline Arctotherium tarijense & Pali Aike Nacional Park, Chile & & $\begin{array}{l}\text { Solbelzon (2002), Prevosti et al. } \\
\qquad(2003)\end{array}$ \\
\hline Arctotherium tarijense & Rio Negro, Uruguay & $11,600 \pm 130$ & $\begin{array}{l}\text { Ubilla and Perea, (1999), Soibelzon } \\
\text { et al. (2005) }\end{array}$ \\
\hline
\end{tabular}


not M. darwinii (Gustavo Scillato Yané, personal communication). Panthera onca mesembrina is here considered as indistinguishable from the living jaguar (Panthera onca).

Table 7.5 shows 16 different extinct taxa documented in dated South American units of putative early Holocene age. Other extinct taxa were reported in the Holocene of West Indian islands (ground sloths; Steadman et al., 2005) and Alaskan Bering Sea islands (mammoths; Guthrie, 2003), among others.

The youngest dated remains of extinct fauna in South America (excepting Dusicyon avus) occur in the La Moderna site, Campo Laborde, and Arroyo Seco 2 sites (Fig. 7.3), all in the Pampean area. The fossils recorded at La Moderna include the glyptodonts Neosclerocalyptus (=Sclerocalyptus) and Glyptodon, and an indeterminate mylodontid. They occur in a bed (UL a' of Zetti et al., 1972; see discussion in Politis and Gutiérrez, 1998) transitional between two members of the typical Luján Formation: the Guerrero Member and the Holocene Río Salado Member. According to Politis et al. (1995) and Politis and Gutiérrez (1998), bones of the glyptodont Doedicurus clavicaudatus yielded dates between 7,500 to 7,000 BP. Other authors suggested that some young contaminants could have rejuvenated the samples (Borrero et al., 1998). However, Politis and Gutiérrez (1998) even mention that a sample that gave an older date (LM-2-4; 12,350 \pm $370 \mathrm{BP})$ was redated with a better treatment and gave younger dates $(7,010 \pm 100$ and 7,510 \pm 370 BP; Beukens, 1992, unpublished report fide Politis and Gutiérrez, 1998). Recently, Politis et al. (2003) reported new radiocarbon dates from the soil humates fraction of La Moderna sediments that support the current accepted chronology of ca. 7,000-7,500 BP.

In the Arroyo Seco 2 site, a diverse extinct fauna was dated from 12,240 $\pm 110 \mathrm{BP}$ to 7,320 $\pm 50 \mathrm{BP}$ (Politis et al., 1995, 2004). It includes Megatherium americanum, cf. Mylodon, Glossotherium robustum, Equus (Amerhippus) neogeus, Hippidion sp., Toxodon platensis, Macrauchenia patachonica, and Hemiauchenia sp. (Fidalgo et al., 1986; Tonni, 1990; Politis et al., 1995; Politis and Gutiérrez, 1998). Only Megatherium americanum, Hippidion sp., and Equus
(Amerhippus) neogeus were argued to have been human food resources at this locality (Politis and Gutiérrez, 1998). In the same site, a human burial accompanied by a grave offering dated at 7,800 to 6,300 BP included a Glyptodon osteoderm close to the human skull with which it seemed to be contemporaneous (Politis and Gutiérrez, 1998).

At the Campo Laborde archeological site, three AMS ${ }^{14} \mathrm{C}$ dates were obtained from Megatherium americanum bones. These dates correspond to the early Holocene, between 7,700 and 8,800 BP (Messineo and Politis, 2006).

A Holocene date $(8,639 \pm 450 \mathrm{BP})$ based on bones of Mylodon, Lama, and horse found at Pali Aike, Santa Cruz, Argentina was considered as a minimal age for that site (see Borrero, 1997).

Gomphotheriidae and Scelidotherinae remains were found in a bed overlying mylodontine remains dated 8,660 \pm 150 BP in Tafí del Valle (Tucumán; Collantes et al., 1993).

In northern Uruguay, Suárez (2003) reports Glyptodon remains at a cultural component dated between 9,120 \pm 40 $\mathrm{BP}$ and 8,570 $\pm 150 \mathrm{BP}$.

Bones of Dusicyon avus, without evidence of human association, were recovered from levels dated at 4,865 \pm 65 $\mathrm{BP}$ in the Cueva Tixi and also in youger beds at Zanjón Seco 2, both in the Pampean area (Politis et al., 1995; Mazzanti and Quintana, 1997). The late disappearance of the species Dusicyon avus was not considered as a real extinction but a hybridation with other canids (Berman and Tonni, 1987). A date of 4,300 BP for a carapace of a glyptodont (Rosello et al., 1999) was considered unsupported by Cione et al. (2001).

In summary, we counted at least 52 species and 38 genera of confirmed extinct mammals in beds deposited between 20,000 to 10,000 (probably 7,000) BP in South America. These taxa certainly disappeared in the last massive extinction. There are many other mammals documented in Lujanian beds of South America for which we do not have certitainty if they reached this period (Table 7.1). Future work will confirm or reject this hypothesis.

Table 7.5 Extinct mammal taxa documented in dated South American units of putative early Holocene age

\begin{tabular}{|c|c|c|}
\hline Taxa & Locality & Reference \\
\hline $\begin{array}{l}\text { Doedicurus clavicaudatus, Sclerocalyptus, } \\
\text { Glyptodon, Scelidotherinae indet., } \\
\text { Megatherium americanum, probably } \\
\text { Glossotherium robustum, Equus } \\
\text { (Amerhippus) neogeus, Hippidion, Toxodon } \\
\text { platensis, Macrauchenia patachonica, } \\
\text { Hemiauchenia, Gomphotherildae, Dusicyon } \\
\text { avus. }\end{array}$ & $\begin{array}{l}\text { Pampean area, Tucumán, and Patagonia } \\
\text { of Argentina and southern Chile }\end{array}$ & $\begin{array}{l}\text { Fidalgo et al. (1986), Coliantes et al. (1993), } \\
\text { Politis et al. (1995), Borrero (1997), Borrero } \\
\text { et al. (1998), Politis and Gutierrez (1998) }\end{array}$ \\
\hline $\begin{array}{l}\text { Eremotherium mirabile, Stegomastodon waringi, } \\
\text { Arctotherium wingei }\end{array}$ & Cedeño District, Venezuela & Linares (1993), Linares \\
\hline
\end{tabular}




\section{Mammal Biogeography during the Last Glacial and Postglacial}

South America is a continent marked by the Andean influence and the remarkable latitudinal extension (see Cabrera and Willink, 1973). Most of the knowledge about latest Pleistocene mammals is based on fossils from southern South America. However, increasing records and new systematic studies allow recognition of patterns of distribution of many species (e.g., Cione et al., 2005; Scillato-Yané et al., 2005; Soibelzon et al., 2005). Some species were wide-ranging in the continent (e.g. Smilodon, Panthera, Arctotherium, Equus, Hippidion, Hemiauchenia). We devised several geographic patterns for several large mammal and megamammal taxa (Fig. 7.4). Notwitstanding the different distribution patterns, all became extinct.

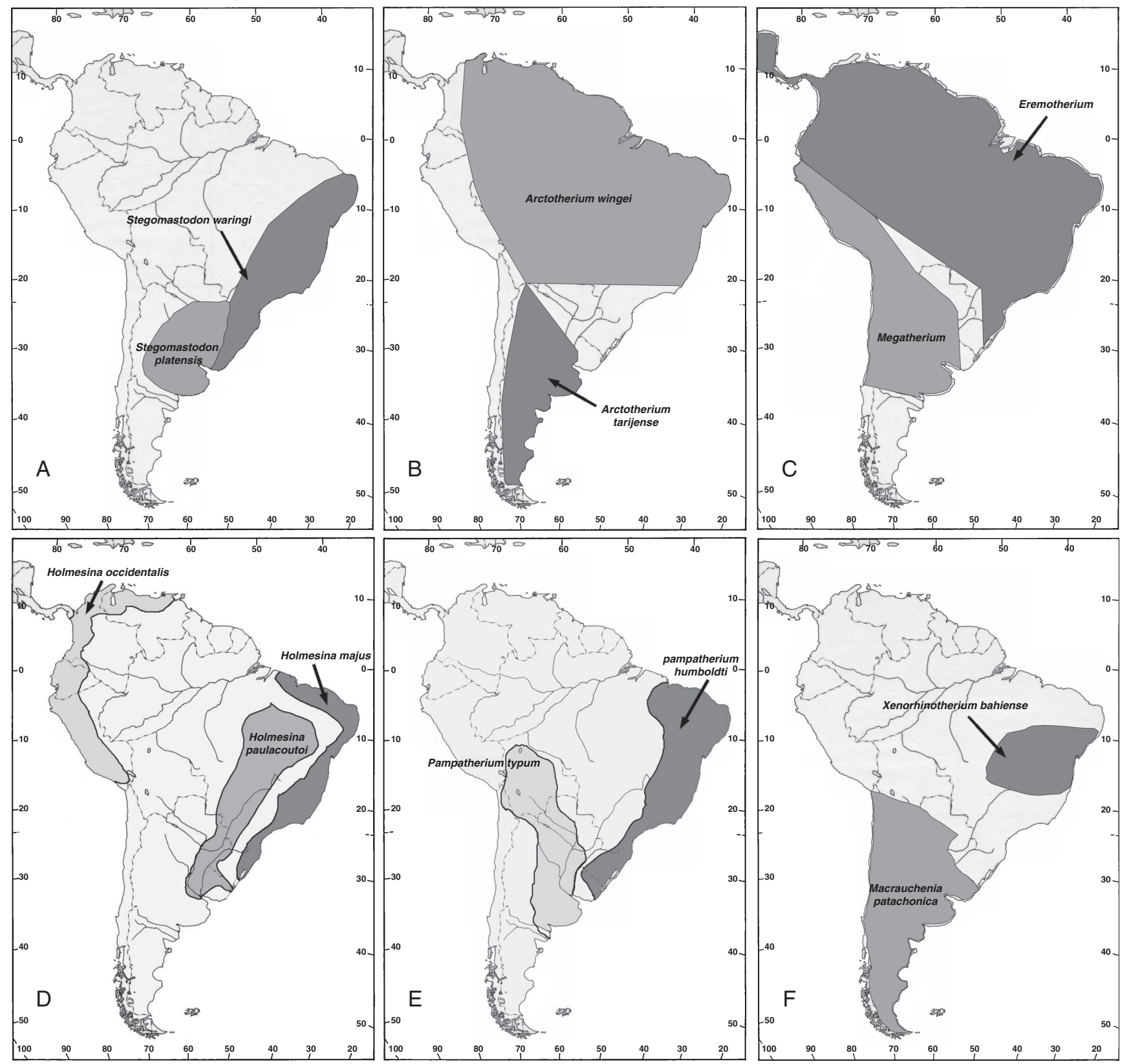

Fig. 7.4 Distribution of some extinct large and megamammals in South America during the Late Pleistocene. A. Stegomastodon waringi and S. platensis (modified from Cione et al., 2005); B. Arctotherium tarijense and $A$. wingei (Soibelzon et al., 2005); C. Eremotherium and Megatherium (Cartelle, 1994; Pujos and Salas, 2004); D. Holmesina majus, H. occi- dentalis and $H$. paulacoutoi (modified from Scillato-Yané et al., 2005); E. Pampatherium typum and P. humboldti (modified from Scillato-Yané et al., 2005); F. Xenorhinotherium bahiense and Macrauchenia patachonica (Melo et al., 2005; Carlini and Tonni, 2000) 


\section{Oldest Human Presence in South America}

In South America, archeological evidence indicates that the continent was occupied by several distinct groups at the end of the Pleistocene (around 13,000-11,000 BP; Borrero et al., 1998). Some of the dated sites with humans for this period are: Taima Taima (ca. 13,000 BP) and El Jobo complex (both sites in the Estado de Falcón,Venezuela; see Gruhn and Bryan, 1984; Politis and Gutiérrez, 1998); Tibitó, Bogotá basin, Colombia, dated 11,740 \pm 110 BP (see Gruhn, 1997); four different cultural complexes in Peru dated between 10,000 and 12,000 BP (Cardich, 1977); Quereo, near Los Vilos, Chile, dated 11,600 \pm 190 BP (see Gruhn, 1997); Tagua Tagua, Chile, dated 10,200 BP and 9,900 BP (Núñez et al., 1994); Monte Verde, a site with mastodont and paleocamelid remains located in southern Chile dated ca. 12,000 BP (Dillehay, 1989; however, also see Fiedel, 1999); Pedra Pintada, Amazonia, Brazil, dated ca. 11,100 BP (Roosevelt et al., 1996); Lapa do Boquete, Minas Gerais, Brazil, dated 12,070 BP to 11,000 BP (see Gruhn, 1997); Abrigo de Santana do Riacho, Minas Gerais, Brazil, dated 11,960 \pm 250 BP (see Gruhn, 1997); for supposed dates of ca. 13,000 BP in southern Brazil, see Schmidt Dias and Jacobus (2002); Los Toldos (11 level of Los Toldos, Santa Cruz, Argentina, dated 12,600 \pm 600 BP; Cardich (1977); Cueva del Lago Sofía, Santa Cruz, Argentina, dated 12,990 \pm 490 BP and 11,570 \pm 60 BP; Politis et al., 1995), Tres Arroyos (Tierra del Fuego, Argentina, dated 11,800 \pm 250 BP; Politis et al., 1995); Cerro La China and Cerro El Sombrero, Argentina, dated ca. 11,000-10,000 BP (Flegenheimer and Zárate, 1997); and the Piedra Museo site, Santa Cruz, Argentina, which corresponds to a time between 12,890 and 10,300 BP (Miotti, 1993; Miotti and Cattáneo, 1997; Borrero et al., 1998; Ramírez Rozzi et al., 2001).

In the Holocene, there are many localities with cultural remains or human bones, some of which are of putative early Holocene age and include extinct fauna (see above).

The oldest widely accepted human presence in North America south of Alaska is dated at about 11,500 BP (Pielou, 1992: 112; Ward, 1997; Haynes, 2002; but see Fiedel, 1999).

\section{Discussion}

\section{Climate When Humans Entered in South America}

After the last glacial maximum (LGM; 20,000-18,000 BP), temperatures began to rise (Clapperton, 1993a,b; Petit et al., 1999; Thompson, 2000; Blunier and Brook, 2001; Steig, 2006).
However, climate appears to have continued to be relatively dry in South America for several thousand years and humans seem to have entered southern South America when climate was still relatively dry (Fig. 7.1; Iriondo, 1997, 1999; Carignano, 1999; Tonni et al., 1999a). Ice cores from South America, Greenland, and Antarctica indicate that there was a peak of temperature followed by a decrease at about 12,700 and 10,300 BP (the Antarctic Cold Reversal and the Younger Dryas chronozone; see McCulloch et al., 2000). After this, there was a steep increase in temperature near the Pleistocene-Holocene boundary (Fig. 7.1; Thompson, 2000; McCulloch et al., 2000). In the Pampean area, at about 10,000 BP, development of dated paleosols indicate a change to wetter conditions (Fidalgo et al., 1975; Tonni and Fidalgo, 1978; Zárate et al., 1995; Prieto, 1996; Tonni et al., 1999a; Cione et al., 2001: Figure 5. This series of climatic events is in agreement with ice cores and other temperature evidence (Thompson, 2000; McCulloch et al., 2000). Consequently, a substantial change to warmer and wetter climate occurred in South America at about 10,000 BP. During the Holocene Climatic Optimum, humid conditions were also documented in Argentina and Brazil (see Tonni et al., 2001; Vivo and Carmignotto, 2004).

According to the ice record in Greenland and Antarctica and to the local evidence, the present interglacial is not essentially different enough from the precedent ones to have caused extinctions.

\section{Which Animals Became Extinct?}

The extinctions were notably size-selective. In North America, some very large mammals (below the size of megamammals, but weighing almost a ton) survived the great extinction (e.g. bison, polar bear). In South America there are no very large mammals, because no megamammal survived.

Regarding the extinct taxa in South America, more than $70 \%$ of megamammal species and $55 \%$ of the large mammal species were xenarthrans (this figure results from the most recent revisions; see Scillato-Yané et al., 1995; Carlini et al., 1999). No megaxenarthran and only one large xenarthran survived. On the contrary, no small xenarthran became extinct, notwithstanding that there were many medium-sized and small xenarthrans present. As well, the last notoungulates, litopterns, and gomphotheriids disappeared.

Of the 14 species of large mammals that presently occur in South America, 12 are of Holarctic origin and two are of South American origin. The proportion of extinct mammals of South American origin is large because almost all the large xenarthrans and all litopterns and notoungulates disappeared (Tonni et al., 1992; Cione et al., 1999). Only one large xenarthran (Priodontes maximus) and a caviomorph (Hydrochoerus hydrochaeris) survived the large mammal extinction. A small 
Table 7.6 Extinct mammals with a body mass under $44 \mathrm{~kg}$

\begin{tabular}{llll}
\hline Taxa & Locality & South American age/stage & Reference \\
\hline Canis dirus & Peru & Lujanian & Hoffstetter (1970) \\
Dusicyon avus & Argentina & Lujanian-Platan & Berman and Tonni (1987) \\
Protocyon orcesi & Ecuador & Bonaerian-Lujanian & Hoffstetter (1970) \\
Protocyon troglodytes & Brazil & Lujanian & Cartelle (1994) \\
Valgipes deformis & Brazil & Lujanian & Cartelle (1994) \\
Eligmodontia $n$. sp. & Argentina & Lujanian & Pardiñas (1999) \\
Microcavia robusta & Argentina & Lujanian & Quintana (1996) \\
Ctenomys lujanensis & Argentina & Lujanian & Morgan (1999) \\
Desmodus draculae & & Lujanian & Morgan (1999) \\
Protopithecus brasiliensis & Brasil & Lujanian & Cartelle (1994) \\
\hline
\end{tabular}

number of extinct mammals with a body mass under $44 \mathrm{~kg}$ is documented in Table 7.6.

Consequently, the latest Quaternary extinction in South America was strongly biased towards large mammals and megamammals (about $90 \%$ of the species; Table 7.1), including those of both South American and Holarctic origin.

\section{South American Extinct Mammals were Adapted to Open Environments}

Although the 83 species of large and mega-mammals that became extinct in South America include species with different feeding habits, nearly all seem to have been adapted to open environments (Webb and Marshall, 1982; Marshall et al., 1984; Bond et al., 1995; Tonni and Scillato Yané, 1997; Table 7.1). Moreover, many were even adapted to arid environments. A possible exception is the capybara Neochoerus aesopy of presumed amphibious habit.

Glyptodonts, tardigrades, toxodonts, equids, and camelids were grazers; litopterns and perhaps gomphotheriids were browsers; daypodiids are omnivores; smilodons, ursids, and the canid Dusicyon avus were carnivores. Although Gomphotheres have been traditionally considered as browsers, grass phytolith assemblages in feces from three individual animals contained similarly high concentrations of pooids, suggesting that grasses were a significant part of the diet. Abundant pooid phytoliths, in addition to diatoms, indicate that these individuals grazed in cool and moist late Pleistocene environments (Gobetz and Bozarth, 2001).

\section{Constraints Related to Life-History Traits in Megamammals and Large Mammals}

Some important megamammal life-history traits may have contributed to the extinction process because they made some species more susceptible to extinction than other mammals (Cione et al, 2003), especially when considered in the context of human hunting.

The age at which sexual maturity is attained is an important factor to be considered since it informs about how long a female must survive in the ecosystem to reach the age of first reproduction. In this regard, the sexual maturity of almost all extant female megammamals is greater than 10 years (Nowak, 1999); hence, a female must survive more than 10 years in nature to have its first offspring.

Johnson (2002) demonstrated correlations of both body mass and reproductive rate with extinction in mammals, and showed that extinction eliminated species at nearly the same threshold of reproductive rate in all groups, regardless of differences between groups in distributions of body size. He found that over all groups, the mean reproductive rate at which the probability of extinction reached 0.5 was 0.98 offspring female ${ }^{-1} \mathrm{yr}^{-1}$. The correlation does not necessarily imply that a female will produce young every year (Nowak and Paradiso, 1983), but does seem to suggest that an average of less than one young per year gives a taxon $<50 \%$ chance of surviving.

The length of the gestation period is positively correlated with body mass in extant eutherian mammals. If we consider only terrestrial mammals, the longest period is that of elephants (668 days). At least in the last third part of that period the female is more vulnerable to predators and hunters due to reduced abilities to take evasive actions related to its added mass.

The length of lactation in mammals ranges almost three orders of magnitude, from 4 to 5 days to over 900 days. Although extremely short lactation lengths $(<10 \mathrm{~d})$ are rare, long lactation lengths ( $>500 \mathrm{~d}$ ) are common for large-bodied species with single offspring (Hayssen and van Tienhoven, 1993). For mammals the length of lactation is positively correlated with adult female mass. The maintenance of the parent and offspring bond during lactation and after weaning is crucial to offspring growth, development, and protection against predators and other threats, as well as necessary for learning from their parents the location of food, nest sites, etc. (Hayssen, 1993). Hence, a young offspring needs its parents (at least its mother) to survive the first years. 
Gregarious behavior of potential prey was explained by Hamilton (1971) on the basis of risk-sharing: the probability of being picked up by a predator is small when one is part of a large aggregate of prey. These defenses were evolved for "natural" predators (i.e., members of the Carnivora) but the Pleistocene humans did not behave the same as natural predators. For example, this is the case of armored xenarthrans, which humans would have hunted differently from carnivores which depended on claws and teeth, weak weapons against the xenarthran defenses. In our view, technology (i. $\mathrm{e}$, the use of fire and rocks and others primitive weapons) and superior intellect constitute the difference between humans and other predators, hence some behavioral defenses of megamammals against natural predators would not be as effective as against humans.

There is correlation between population density and body size, resulting from the simple fact that for animals with similar metabolic processes (e.g., homeotherms), existing at the same trophic level (e.g., herbivores), equal amounts of biomass can be consumed by many individuals (Wagespack and Surovell, 2003). In this sense, it is important to note the amazing differences in population density between taxa with different body masses (see Table 1 in Wagespack and Surovell, 2003). In addition, several lines of theory link abundance with species richness. Clades whose species tend to be locally abundant will produce new species at a faster rate than clades of rare species (Isaac et al., 2005). If speciation rate is directly proportional to global population size (Hubbell, 2001) and abundance is a measure of global population size (Gaston, 1994), then abundance provides a natural buffer against extinction and leads to the accumulation of species (Isaac et al., 2005). Also, Kay (2002) suggests that large mammals and megamammals were few because they were limited in number by predators and, especially during the glacial periods, by the low basic plant productivity (see also Pielou, 1992).

\section{American Mammals were Not Adapted to Humans}

Many of the South American late Pleistocene mammals were of Holarctic origin. However, it is certain that neither these animals nor those of South American origin evolved in contact with humans. Quite certainly, these animals had not developed prevention reflexes against human hunting practices. There is no doubt that Paleoindians both in North and South America were at least occasionally big-game hunters, notwithstanding that they also used other resources for subsistence (Martin and Klein, 1984; Neves and Cornero, 1997; Borrero et al., 1998; Politis and Gutiérrez, 1998; Haynes, 2002).

\section{Which of the Mammals Survived in South America?}

No megamammal survived in South America and the only relatively large mammals that avoided extinction are inhabitants of areas of relatively difficult access for humans, such as (1) forests and cerrados (tapirs, Tapirus terrestris; large armadillos, Priodontes giganteus; peccaries, Catagonus wagneri; and some deers, Blastoceros dichotomus; Hippocamelus bisulcus); (2) mountainous areas (spectacled bear, Tremarctos ornatus; other tapirs, Tapirus pinchaque and Tapirus bairdii; vicuña, Lama vicugna; and deer, Hippocamelus antisensis); and (3) wetlands (carpinchos, Hydrochoerus hydrochaeris; cervids, Ozotoceros bezoarticus) (Johnson, 2002; Cione et al., 2003; Barnosky et al., 2004). Priodontes giganteus has also nocturnal habits. Other large tetrapods that survived are the more fully aquatic vertebrates such as river dolphins, manatees, seals, sea lions, and caimans; see Cione et al., 2000). The other survivors are some eurytopic species such as large carnivores (Panthera onca, Puma concolor). The guanaco is a special case because it is one of the most frequently cited taxa in archeological sites, but once again we could find an explanation in its lifehistory traits: the age of maturity in females is one year, the gestation period is 335 days, the reproductive rate is one offspring a year, the lactation period is six to 12 weeks and the parental care lasts one year, and the population density is 2.13 individual $\mathrm{km}^{2-1}$ (Sarno and Franklin, 1999; Nowak and Paradiso, 1983; Montes et al., 2000). Consequently, guanaco does not appear to be a species easy to extinguish. Besides, guanacos are fast, numerous, and have montane populations. In addition, there is evidence in the Andean region of early domestication of the guanacos (Pires Ferreira et al., 1976; F. Pujos, personal communication). The jaguar and puma include a large variety of prey in their diets and certainly were not especially adapted to feed on only those big herbivores that became extinct.

\section{Man as a Hunter}

Waguespack and Surovell (2003; also, this volume)) analyzed the zooarcheological record of North America and arrived at the conclusion that North American Paleoindians were big game specialists. The ratio between hunt effort and food obtained is obviously higher for a megammamal than for others mammals. Recently some authors (Grayson and Meltzer, 2003; Cannon and Meltzer, 2004) have expressed doubts about the role of man as a megafaunal specialist hunter. However, this is not indispensable for explaining the South American extinction. 
Lyons et al. (2004) analyzed the presently threatened and endangered mammals and found that those mammals menaced by human hunting were significantly larger than those subject to different extinction pressures. Thus, the prediction that early human hunters preferentially targeted large mammals is substantiated by modern hunting practices. In the scenario presented here a blitzkrieg is not necessary to explain the extinction. Only a moderate and occasional hunting of females (solitaries or with offsprings), juveniles, or offsprings is necessary to produce extinction in a few thousand years. Certainly, most xenarthrans would be not difficult to kill by trained hunters. Moreover, we consider that there was no time after the entrance of humans to allow the megamammals to evolve biological compensations for avoiding extinction.

The archeological evidence indicates that the overhunting was focused on guanacos and deer, which, paradoxically, are those mammals that survived the extinction. The scarcity or infrequent occurrence of megammamals in archeological sites more likely implies that these mammals were less abundant in the area, not that they were ignored or inaccessible to humans (see also Kay, 2002). Note that horses are infrequent in the archeological sites but were not more difficult to hunt than guanaco or deer; hence, a possible explanation is a reduced population. Another explanation is provided by Gary Haynes's observations (in Fiedel and Haynes, 2004) on modern killsites (both cultural and non-cultural) in Africa. Haynes observed that modern death sites are rarely preserved (less than $0.01 \%$ or less of total number being killed or dying naturally). Indirect evidence of hunting of some large mammals not recorded in archeological contexts was obtained from blood residue on lithic points (Kooyman et al., 2001). In South America, more than 15 extinct large mammals and megamammals were reported in association with Paleoindian sites (see above). However, many marks on bones should be taken with precaution as a direct evidence of hunting (F. Martin, 2003; pers. comm.)

\section{How Many Humans were Required for the Extinction?}

Simulations of human foraging on multiple prey yield the idea that overkill of slowbreeding prey is more likely when hunter populations became large (see Barnosky et al., 2004). However, according to the model of Alroy (2001), the number could be small (see also Kay, 2002), especially if we consider the putative reduced number of megamammals and large mammals in the continent (see above; see also Haynes, this volume).

\section{Large Extinct Carnivores}

Large carnivores such as the short-faced bears of genus Arctotherium and the large saber-tooth cat Smilodon populator also became extinct (Soibelzon, 2002). Using phylogenetic comparative methods, Cardillo et al. (2004) show that extinction risk in the mammal order Carnivora is predicted more strongly by biology than exposure to high-density human populations. What was the human impact on carnivores competing for prey and carcasses? As Van Valkenburgh (2001) explains for Africa, if early Homo was consuming large prey regularly, it is probable that prey were often acquired by confrontational scavenging, as well as perhaps hunting, and this would be possible only because Homo had sufficient intelligence to overcome the superior strength, speed, and weaponry of the many other predators. Moreover, if we consider that humans who first inhabited America had advanced weaponry technology, it is easy to imagine that the resource competition with the medium to large carnivore/omnivore fauna was probably unequal. In this regard, we wonder what was the responsibility of man in the extinction of the medium to large carnivores/omnivores.

On the other hand, the absence or reduced number of top predators in the ecosystem could have large effects on the structure of the entire community. Both empirical and theoretical studies have shown that the loss of a top predator can trigger a cascade of secondary extinctions (Borrvall and Ebenman, 2006, and papers cited therein).

Wilmers and Getz (2005) and Wilmers and Post (2006) demonstrated that the presence of top predators provide insurance against the effects of climatic change. Wilmers et al. (2006) studied the consequences of the absence of wolves in two ecosystems and concluded that the top predators have buffering effects on changes in populations numbers (of other taxa) caused by climatic variations. Regardless of the importance of specific predators in particular systems, Wilmers et al.'s (2006) findings strongly support the hypothesis that intact food webs including top predators appear to be more resistant to stress. Bottom-up factors thus appear to be more important when food chains are shortened and topdown control is reduced (Sala, 2006).

We do not reject the possibility that some herbivores could also have been exterminated by cascade effects (see OwenSmith, 1987).

\section{Timing of Extinction in the Americas}

From a biogeographic point of view, if humans first entered South America from North America, and if the extinction was caused by them, it would have to be accomplished earlier 
in North America than in South America. Not surprisingly, the youngest records of extinct mammals in North America are dated at 10,370 BP (i.e., latest Pleistocene; Beck, 1996) while in South America, the youngest records appear to correspond to the early Holocene. However, the dispersal of humans in South America could have been very fast. Youngblood (2002) calculated that humans could have traveled from Beringia to central Chile in 250 years. Available evidence suggests that the extermination process lasted longer in South America than in North America. This long lasting process could have been related to the peculiar climatic history and biocenotic evolution of each continent.

\section{In Summary}

The distribution and biomass of the flora and fauna had strongly fluctuated many times during the middle-late Pleistocene in a Zig-Zag but we have not identified important extinctions until the end of the Pleistocene and the beginning of the Holocene. However, almost all living mammal species make their first appearance in the Pleistocene (Lister, 2004).

The studies based on geochemical and dust proxies in Greenland, Antarctica, and South American glaciers attest that the present interglacial is not substantially different to the precedent ones.

The arrival of humans in South America was the sole new biological or geological event that occurred in the present interglacial.

The late Pleistocene and earliest Holocene South American mammal fauna was very different from the Recent not only by the presence of many extinct very large mammals but also because of the different distribution of many animal and plant species.

All megamammals (37 species) and most large mammals (46 species) present during the late Lujanian (latest Pleistoceneearliest Holocene) became extinct in South America. Several did not overlap their geographical distributions.

Many of the extinct mammals were large and scarce. Females probably reached sexual maturity late, had a very long gestation period (one year or more), and prolonged parental care, implying one offspring in two or three years, and had a total low number of offsprings during life.

Pleistocene megamammals and extinct large mammals were mostly adapted to open areas. The shrinking of open areas in the interglacials (including the present) provoked population fragmentation. Thus, the populations that originally inhabited the large open areas became isolated in large "islands" (see Haynes, this volume, and the discussion of sources and sinks). The consequences of population isolation is gene flow interruption. The main disadvantage associated with gene flow interruption is the loss of genetic variability which offers some population "resistance" to new diseases, environmental severities, etc., and the emergence of genetic problems associated with inbreeding. On the other hand, natural barriers prevented dispersal of species to counteract local extinctions.

The few large mammals that survived (14 species) are adapted to forests, mountainous areas, or wetlands, or at least some populations inhabit these kinds of environments. Some have nocturnal habits. Other large vertebrates usually not considered in the extinction discussion, such as pinnipeds, manatees, and caimans, inhabit protected aquatic environments.

Shortly after humans entered South America, climate changed and open areas began to shrink, especially after the beginning of the Holocene.

It has been documented that humans hunted many of the mammals that became extinct. The ratio between hunt effort and food obtained is obviously higher for a megammamal than other mammals.

The extinction appears to have been more concentrated in taxa of South American origin. However, this is mainly apparent because many of the large mammals were xenarthrans (and litopterns and notoungulates).

Contrasting with North America, recent dating suggests that several megamammals became extinct in South America during the early Holocene (perhaps as late as 7,000 BP). As humans entered South America ca. 13,000-11,000 BP, the process of extinction endured several thousand years (perhaps up to 6,000 years). So, chronological evidence does not support the blitzkrieg model for South America.

The extinction event in South America was the largest in the world at the time and perhaps the youngest one at a large scale.

We believe that in the particular situation of a dramatic shrinking of geographic range and the number of large, mostly slow and naive mammals, a relatively small number of active foragers with specialized weapons would have been able to exterminate many of them after no more than several thousand years of cohabitation. Perhaps only a moderate and occasional hunting of females (solitaries or with offsprings), juveniles, or offsprings would be necessary to produce their extinction in few thousand years. Quite certainly, when populations diminished to a threshold, they became not viable anymore. With the demise of many mammals and the taking of other actions such the use of fire, humans altered the ecologic equilibrium of the continent, provoking other extinctions in cascade. The large carnivores such as Smilodon populator probably became extinct when their preferred prey victims disappeared.

Finally, it is plausible that without the appearance of humans in the continent, the extraordinarily varied fauna of large 
mammals and megamammals that characterized South America during the Pleistocene should have recovered and survived, as it had occurred after each of the previous interglacial periods.

Acknowledgments The authors would like to thank the following institutions and workers: For the invitation to participate in this book: Gary Haynes. For the valuable reviewing that permitted great improvement of the manuscript: Gary Haynes and two anonymous referees. For valuable information: Luis Borrero, María Susana Bargo, Mariano Bond, Marcel Cardillo, Alfredo Carlini, Bo Ebenman, Stuart Fiedel, Jean-Michel Gaillard, Donald Grayson, Nick Isaac, Charles Kay, Jennifer Leonard, Omar Linares, Adrian Lister, Kate Lyons, Fabiana Martin, Gustavo Politis, Francisco Prevosti, François Pujos, Gustavo Scillato Yané, Tony Stuart, Sergio Vizcaíno, Nicole M. Waguespack, Lars Werdelin, and Alfredo Zurita. For financial support: Consejo Nacional de Investigaciones Científicas y Técnicas, Comisión de Investigaciones Científicas de la Provincia de Buenos Aires, Agencia Nacional de Promoción Científica y Tecnológica, and Universidad Nacional de La Plata.

\section{References}

Aguirre ML, Whatley RC (1995) Late Quaternary marginal marine deposits and palaeoenvironments from northeastern Buenos Aires province, Argentina: A review. Quat Sci Rev 14:223-254

Alberdi MT, Menegaz A, Prado JL, Tonni EP (1988) La fauna local Quequén Salado-Indio Rico (Pleistoceno tardío) de Buenos Aires, Argentina. Aspectos paleoambientales y bioestratigráficos. Ameghiniana 25:225-236

Alberdi MT, Prado JL (1992) El registro de Hippidion Owen 1869 y Equus (Amerhippus) Hofftetter 1950 (Mammalia, Perissodactyla) en América del sur. Ameghiniana 29:265-284

Alberdi MT, Miotti L, Prado JL (2001) Hippidion saldiasi Roth 1899 (Equidae, Perissodactyla) at the Piedra Museo site (Santa Cruz, Argentina): Its implication for the regional economy and enviromental reconstruction. J Archaeol Sci 28:411-419

Alroy J (2001) A multispecies overkill simulation of the end-Pleistocene megafaunal mass extinction. Science 292:1893-1896

Ameghino F (1889) Contribución al conocimiento de los mamíferos fósiles de la República Argentina. Actas de la Academia Nacional de Ciencias en Córdoba 6:1-1027

Aramayo SA (1997) Cronología radiocarbónica de localidades fosilíferas pleistocenas y holocenas de la costa sud-sudeste de la provincia de Buenos Aires, Argentina. Atas do VI Congresso da Associação Brasileira do Estudos do Quaternário, Curitiba, Brazil, pp 305-308

Arribas A, Palmquist P, Pérez-Claros JA, Castilla R, Vizcaíno SF, Fariña $R$ (2001) New evidence on the interaction between humans and megafauna in South America. XVII Jornadas Sociedad Española de Paleontología, Valencia, Spain, pp 228-238

Bard E, Hamelin B, Fairbanks RG, Zindler A (1990) Calibration of the $14 \mathrm{C}$ timescale over the past 30,000 years using mass spectometric U-Th ages from Barbados corals. Nature 345:405-410

Barnosky AD, Koch PL, Feranec R, Wing SSL, Shabel AB (2004) Assessing the causes of late Pleistocene extinctions on the continents. Science 306:70-75

Beck M (1996) On discerning the cause of late Pleistocene megafaunal extinctions. Paleobiology 22:91-103

Behling H (2002) South and southeast Brazilian grasslands during Late Quaternary times: A synthesis. Palaeogeogr Palaeocl 177:19-27

Behling H, Arz H, Pätzold J, Wefer G (2002) Late Quaternary vegetational and climate dynamics in southeastern Brazil, inferences from marine cores GeoB 3229-2 and GeoB 3202-1. Palaeogeogr Palaeocl 179:227-243

Behling H, DePatta Pillarb V, Girardi Bauermann S (2005) Late Quaternary grassland (Campos), gallery forest, fire and climate dynamics, studied by pollen, charcoal and multivariate analysis of the São Francisco de Assis core in western Rio Grande do Sul (southern Brazil). Rev Palaeobot Palynol 133:235-248

Berman D, Tonni EP (1987) Canis (Dusicyon) avus Burmeister,1864 (Carnivora, Canidae) en el Pleistoceno tardío y Holoceno de la provincia de Buenos Aires. Aspectos sistemáticos y bioestratigráficos relacionados. Ameghiniana 24:245-250

Blunier T, Brook EJ (2001) Timing of millenial-scale climate changes in Antarctica and Greenland during the last glacial period. Science 291:109-112

Bond M, Cerdeño E, López GM (1995) Los ungulados nativos de América del Sur. In: Alberdi MT, Leone G, Tonni EP (eds) Evolución biológica y climática de la región pampeana durante los últimos cinco millones de años. CSIC Monografías 12:257-277

Borrero LA (1997) La extinción de la megafauna en la Patagonia. Anales del Instituto de la Patagonia 23:89-102

Borrero LA, Zárate M, Miotti L, Massone M (1998) The PleistoceneHolocene transition and human occupations in the southern cone of South America. Quat Intl 49/50:191-199

Borrvall C, Ebenman B (2006) Early onset of secondary extinctions in ecological communities following the loss of top predators. Ecol Lett 9:435-442

Broecker W (2001) Was the medieval warm period global? Science 291:1497-1499

Cabrera AL, Willink A (1973) Biogeografía de América Latina. Programa de Desarrollo Científico y Tecnológico, Serie Biología 13:1-120

Cannon MD, Meltzer DJ (2004) Early Paleoindian foraging: Examining the faunal evidence for large mammal specialization andregional variability in prey choice. Quat Sci Rev 23:1955-1987

Cardich A (1977) Las culturas pleistocénicas y postpleistocénicas de Los Toldos y un bosquejo de la prehistoria de Sudamérica. Obra del Centenario del Museo La Plata 2:149-172

Cardillo M, Purvis A, Sechrest W, Gittleman JL, Bielby J, Mace GM (2004) Human Population density and extinction risk in the world's carnivores. PLoS Biology 2:909-914

Carignano C (1999) Late Pleistocene to recent climate change in Córdoba Province, Argentina: Geomorphological evidence. Quat Intl 57/58:117-134

Carlini AA, Scillato Yané G (1999) In: Tonni, E. P., Cione, A. L. (Eds.), Quaternary vertebrate palaeontology in South America. Quat South Am Antarctic Peninsula 12:149-175

Carlini AA, Zurita AE (2006) Glyptotherium Osborn (Mammalia, Xenarthra, Cingulata) en el Pleistoceno Tardío de Venezuela. Abstracts $9^{\circ}$ Congreso Argentino de Paleontología y Bioestratigrafía, p 98

Carlini AA, Tonni EP (2000) Mamíferos fósiles del Paraguay. SEAM. BGR, La Plata.

Cartelle, C. 1994. Tempo passado. Mamiferos do Pleistoceno em Minas Gerais. Palco Ed., Brasilia

Casamiquela R (1999) The Pleistocene vertebrate record of Chile. In: Tonni EP, Cione AL (eds) Quaternary vertebrate paleontology in South America. Quat South Am Antarctic Peninsula 12:91-107

Cione AL, Azpelicueta MM, Bond M, Carlini AA, Casciotta JR, Cozzuol MA, de la Fuente M, Gasparini Z, Goin FJ, Noriega J, Scillato-Yané GJ, Soibelzon LH, Tonni EP, Verzi D, Vucetich MG (2000) Miocene vertebrates from Paraná, Eastern Argentina. In: Aceñolaza FG, Herbst R (eds) El Neógeno de Argentina INSUGEO, serie Correlación Geológica 14:191-237, Tucumán

Cione AL, López Arbarello A (1994) La ictiofauna del Bajo San José (provincia del Buenos Aires, Pleistoceno temprano). Su significación paleoambiental y paleobiogeográfica. VICongreso Argentino de Paleontología y Biostratigrafía, Trelew, Argentina, pp 22-23 
Cione AL,Tonni EP (1995) Chronostratigraphy and "Land-mammal ages" in the Cenozoic of southern South America: Principles, practices, and the "Uquian" problem. J Paleontol 69:135-159

Cione AL,Tonni EP (1996) Reassesment of the Pliocene-Pleistocene continental time scale of southern South America. Correlation of the Chapadmalalan with Bolivian sections. J South Am Earth Sci 9:221-236

Cione AL,Tonni EP (1999) Biostratigraphy and chronological scale of uppermost Cenozoic in the pampean area, Argentina. In: Tonni EP, Cione AL (eds) Quaternary vertebrate palaeontology in South America. Quat South Am Antart Peninsula 12:23-51

Cione AL, Tonni EP (2001) Correlation of Pliocene to Holocene southern South American and European mammal-bearing units. Boletin della Società Paleontologica Italiana 40:167-174

Cione AL, Tonni EP, Bond M, Carlini AA, Pardiñas UF, Scillato Yané GJ, Verzi, D., Vucetich MG (1999) Occurrence charts of Pleistocene mammals in the Pampean area, eastern Argentina. In: Tonni EP, Cione AL (eds) Quaternary vertebrate palaeontology in South America. Quat South Am Antart Peninsula 12:53-59

Cione AL, Tonni EP (2005) Bioestratigrafía basada en mamíferos del Cenozoico superior de la región pampeana. In: Barrio R, Etcheverry RO, Caballé MF, Llambías E (eds) Geología y Recursos Minerales de la Provincia de Buenos Aires. Relatorio del XVI Congreso Geológico Argentino. La Plata 11:183-200

Cione AL, Tonni EP, Figini AJ (2001) Did the megafauna range to 4,300 yr BP in South America? Radiocarbon 43:69-75

Cione AL, Tonni EP, Soibelzon LH (2003) The broken zig-zag: Late Cenozoic large mammal and turtle extinction in South America. Revista del Museo Argentino de Ciencias Naturales "Bernardino Rivadavia" 5:1-19

Cione AL, Tonni EP, Dondas A (2005) A mastodont (Mammalia, Gomphotheriidae) from the Argentinian continental shelf. Neues Jahrbuch für Geologie und Paläontologie, Mitteilungen 2005:614-630

Clapperton C (1993a) Nature and environmental changes in South America at the Last Glacial Maximum. Palaeogeogr Palaeocl 101:189-208

Clapperton C (1993b) Quaternary geology and geomorphology of South America. Elsevier, Amsterdam

Coltorti M, Ficcarelli G, Jahren H, Moreno Espinosa M, Rook L, Torre D (1998) The last occurrence of Pleistocene megafauna in the Ecuadorian Andes. J South Am Earth Sci 11:581-586

Collantes M, Powell J, Sayago JM (1993) Formación Tafí del Valle (Cuaternario superior), provincia de Tucumán (Argentina): Litología, paleontología y paleoambientes. Actas XII Congreso Argentino de Geologia y II Congreso Exploración de Hidrocarburos 1:200-206

Cook KH, Vizy EK (2006) Delayed onset of the South American summer monsoon during the Last Glacial Maximum. PAGES News, pp $17-18$

Deschamps CM (2005) Late Cenozoic mammal bio-chronostratigraphy in southwestern Buenos Aires Province, Argentina. Ameghiniana 42:733-750

Dillehay T (1989) The cultural relationships of Monte Verde: A late Pleistocene settlement site in the Subantarctic forest of South central Chile. In: Bryan AL (ed) New evidence for the Pleistocene peopling of the Americas, Center for the Study of Early Man, University of Maine, Orono, pp 319-337

Ferigolo J (1999) Late Pleistocene South American land-mammal extinctions: The infection hypothesis In: Tonni EP, Cione AL (eds) Quaternary vertebrate palaeontology in South America. Quat South Am Antart Peninsula 12:279-310

Ficcarelli G, Azzaroli A, Bertini A, Coltorti M, Mazza P, Mezzabotta C, Moreno Espinosa M, Rook L, Torre D (1997) Hypothesis on the cause of extinction of the South American mastodonts. J South Am Earth Sci 10:29-38
Fidalgo F (1992) Provincia de Buenos Aires. Continental. In: Iriondo M (ed) El Holoceno de Argentina. Cadinqua, Buenos Aires

Fidalgo F, De Francesco F, Pascual R (1975) Geología superficial de la llanura bonaerense. Relatorio VI Congreso Geologico Argentino, pp 103-138

Fidalgo F, Meo Guzmán LM, Politis GG, Salemme M, Tonni EP (1986) Investigaciones arqueológicas en el sitio 2 de Arroyo Seco (Pdo. de Tres Arroyos-Provincia de Buenos Aires, República Argentina). In: Bryan AL (ed) New evidence for the Pleistocene peopling of the Americas. Center for the Study of Early Man, University of Maine, Orono, pp 221-269

Fiedel SJ (1999) Older than we thought: Implications of corrected dates for Paleoindians. Am Antiquity 64:95-115

Fiedel S, Haynes G (2004) A premature burial: Comments on Grayson and Meltzer's "Requiem for overkill". J Archaeol Sci 31:121-131

Figini A, Fidalgo F, Huarte R, Carbonari J, Gentile R (1995) Cronología radiocarbónica de los sedimentos de la Formación Luján en Arroyo Tapalqué, provincia de Buenos Aires. IV Jornadas Geologicas y Geofisicas Bonaerenses, Junín, Argentina, pp 119-126

Flegenheimer N, Zárate M (1997) Considerations on radiocarbon and calibrated dates from Cerro La China and Cerro El Sombrero, Argentina. Curr Res Pleistocene 14:27-28

Gaston KJ (1994) Rarity. Chapman \& Hall, London

Gobetz K, Bozarth S (2001) Implications for Late Pleistocene mastodon diet from opal phytoliths in tooth calculus. Quat Res 55:115-122

Graham RW (1986) Plant-animal interactions and Pleistocene extinctions. In: Elliott DK (ed) Dynamics of extinction. Wiley, New York, pp 131-154

Graham RW, Lundelius EL Jr (1984) Coevolutionary disequilibrium and Pleistocene extinctions. In: Martin PS, Klein RG (eds) Quaternary extinctions. A prehistoric revolution. University of Arizona Press, Tucson, pp 223-249

Graham RW, Lundelius EL Jr, Graham M, Schroeder EK, Toomey RS III, Anderson E, Barnosky AD, Burns JA, Churcher C, Grayson D, Guthrie RD, Harington CR, Jefferson GT, Martin LD, McDonald HG, Morlan RE, Semken HA Jr, Webb SD, Werdelin L, Wilson MC (1996) Spatial response of mammals to Late Quaternary environmental fluctuations. Science 272:1601-1606

Grayson DK, Meltzer DJ (2003) Clovis hunting and large mammal extinction: A critical review of the evidence. J World Prehistory $16: 313-359$

Gruhn R (1997) The South American context of the Pedra Pintada site in Brazil. Curr Res the Pleistocene 14:29-31

Gruhn R, Bryan A (1984) The record of Pleistocene Megafaunal extinction at Taima-Taima, northern Venezuela. In: Martin P, Klein R (eds) Pleistocene extinctions: A prehistoric revolution. University of Arizona Press, Tucson, pp 128-137

Hamilton WD (1971) Geometry for the selfish herd. J Theoret Biol 31:295-311

Haynes G (2002) The catastrophic extinction of North American mammoths and mastodonts. World Archaeol 33:391-416

Heusser L, Heusser C, Pisias N (2006) Vegetation and climate dynamics of southern Chile during the past 50,000 years: Results of ODP Site 1233 pollen analysis. Quat Sci Rev 25:474-485

Hayssen V, van Tienhoven A (1993) Asdell's patterns of mammalian reproduction. A compendium of species-specific data. Comstock, Ithaca, NY

Hoffstetter R (1970) Vertebrados cenozoicos y mamíferos cretácicos de Perú. Actas IV Congreso Latinoamericano de Zoología 2:971-983

Hoffstetter R (1986) High andean mammalian faunas during the PlioPleistocene. In: Vuilleumier F (ed) High altitude tropical biogeography. Oxford University, New York

Hubbell SP (2001) The unified neutral theory of biodiversity and biogeography: Monographs in population biology. Princeton University Press, Princeton, NJ

Iriondo M (1997) Models of deposition of loess and loessoids in the Upper Quaternary of South America. J South Am Earth Sci 10:71-79 
Iriondo M (1999) Climatic changes in the South American plains: Records of a continent-scale oscillation. Quat Intl 57/58:93-112

Isaac NJB, Jones KE, Gittleman JL, Purvis A (2005) Correlates of species richness in mammals: Body size, life history, and ecology. The American Naturalist 165:600-607

Johnson CN (2002) Determinants of loss of mammal species during the Late Quaternary 'megafauna' extinctions: Life history and ecology, but not body size. Proc Roy Soc Lond B 269:2221-2227

Kay CE (2002) False gods, ecological myths, and biological reality. In Kay CE, Simmons RT (eds) Wilderness and political ecology. University of Utah Press, Salt Lake City, pp 238-261

Kooyman B, Newman ME, Cluney C, Lobb M, Tolman S, McNeill P, Hills LV (2001) Identification of horse exploitation by Clovis hunters basesd on protein analysis. Am Antiquity 66:686-691

Linares O (1993) Mamíferos megaherbívoros en la Guayana venezolana; indicios de aridez durante el Cuaternario tardío - Holoceno. V Reunión Anual del Proyecto PICG-281 "Climas cuaternarios de América del Sur", Santiago de Chile, Chile, pp 52

Lister AM (2004) The impact of Quaternary Ice Ages on mammalian evolution. Philosoph Trans Roy Soc Lond 359:221-241

Lyons SK, Smith FA, Brown JH (2004) Of mice, mastodons and men: Human-mediated extinctions on four continents. Evol Ecol Res 6:339-358

MacFadden B (2000) Middle Pleistocene climate change recorded in fossil mammal teeth from Tarija, Bolivia, and Upper Limit of the Ensenadan Land-Mammal Age. Quat Res 54:121-131

Marchant R, Boom A, Behlin H, Hooghiemstra H, Melief B, Van Geel B, Van Der Hammen T, Wille M (2004) Colombian vegetation at the Last Glacial Maximum: A comparison of model- and pollen-based biome reconstructions. J Quat Sci 19:721-732

Marshall L, Berta A, Hoffstetter R, Pascual R, Reig OA, Bombin M, Mones A (1984) Mammals and stratigraphy: Geochronology of the continental mammal- bearing Quaternary of South America. Palaeovertebrata Mémoire Extraordinaire, pp 1-76

Martin PS, Klein RG (eds) (1984) Quaternary extinctions. A prehistoric revolution. University of Arizona Press, Tucson

Martínez GA (1997) A preliminary report on Paso Otero 5, a Late Pleistocene site in the Pampean region. Curr Res Pleistocene 14:53-54

Mazzanti DL (1997) Excavaciones arqueológicas en el Sitio Cueva Tixi, Buenos Aires, Argentina. Latin Am Antiquity 8:55-62

Mazzanti DL, Quintana C (1997) Asociación cultural con fauna extinguida en el sitio arqueológico Cueva Tixi, provincia de Buenos Aires, Argentina. Revista Española de Antropología Americana 27:11-21

McCulloch RD, Bentley MJ, Purves RR, Hulton NJR, Sugden DE, Clapperton CM (2000) Climatic inferences from glacial and palaeoecological evidence at the last glacial termination, southern South America. J Quat Sci 15:409-417

Melo DJ de, Cássia Tardin Cassab R de, Ventura dos Passos F (2005) Coleção de mamíferos pleistocênicos de Águas de Araxá, no Museu de Ciências da Terra. X Congresso de ABEQUA eletronic version without pagination

Messineo P, Politis GG (2006) The Campo Laborde site: New evidence for the Holocene survival of Pleistocene megafauna in the Argentine pampas. International Council for Archaeozoology, 10th Conference, abstracts, Mexico, pp 127-128.

Miotti L (1993) La ocupación humana en la Patagonia austral durante el Holoceno. In: Iriondo M (ed) El Holoceno en la Argentina. Cadinqua, Buenos Aires, Argentina, pp 94-130

Miotti L, Cattaneo R (1997) Bifacial/Unifacial technology c. 13,000 years ago in southern Patagonia. Curr Res Pleistocene 14:62-64

Montes C, De Lamo DA, Zavatti J (2000) Distribución de abundancias de guanacos (Lama guanicoe) en los distintos ambientes de Tierra del Fuego, Argentina. Mastozoología Neotropical 7:23-31

Morgan GS (1999) Late-Pleistocene climatic change and neotropical bat extinctions. Current Research in the Pleistocene 16:133-133

Nabel P, Cione AL, Tonni EP (2000). Environmental changes in the Pampean area of Argentina at the Matuyama-Brunhes (C1r-C1n) Chrons boundary. J South Am Earth Sci 162:403-412
Nami HH, Nakamura I (1995) Cronología radiocarbónica con AMS sobre muestras de hueso procedentes del sitio Cueva del Medio (Última Esperanza, Chile). Anales Instituto de la Patagonia 23:125-133

Neves W, Cornero S (1997) What did South American Paleoindians eat? Current Research in the Pleistocene 14:93-96

Nowak RM (1999) Walker's mammals of the world, 6th ed., vols I \& II. Johns Hopkins University Press, Baltimore

Nowak RM, Paradiso JL (1983) Walker's mammals of the world. Johns Hopkins University Press, New York

Núñez L, Varela J, Casamiquela R, Villagrán C (1994) Cuenca de Tagua-Tagua en Chile: el ambiente Pleistoceno Superior y ocupaciones humanas. Revista Chilena de Historia Natural 67:503-519

Owen-Smith N (1987) Pleistocene extinctions: The pivotal role of megaherbivores. Paleobiology 13:351-362

Pardiñas UFJ (1999) Fossil murids: Taxonomy, palaeoecology and biostratigraphy. In: Tonni EP, Cione AL (eds) Quaternary vertebrate palaeontology in South America. Quat South Am Antarct Peninsula 12:225-253

Pardiñas UFJ, Cione AL, San Cristóbal J, Verzi D, Tonni EP (2004) A New Last Interglacial continental vertebrate assemblage in CentralEastern Argentina. Curr Res Pleistocene 21:111-112

Pardiñas UFJ, Gelfo J, San Cristóbal J, Cione AL, Tonni EP (1996) Una asociación de organismos marinos y continentales en el Pleistoceno superior en el sur de la provincia de Buenos Aires, Argentina. Actas XIII Congreso Geológico Argentino y III Congreso de Exploracion de Hidrocarburos 5:95-111

Pascual R, Ortega Hinojosa E, Gondar D, Tonni EP (1965) Las edades del Cenozoico mamalífero de la Argentina, con especial atención a aquellas del Territorio Bonaerense. Anales Comision de Investigaciones Cientificas 6:165-193

Petit JR, Jouzel J, Raynaud D, Barkov NI, Barnola JM, Basile I, Bender M, Chappellaz J, Davis M, Delaygue G, Delmotte M, Kotlyakov V, Legrand M, Lipenkov V, Lorius C, Pepin L, Ritz C, Saltzman E, Stievenard M (1999) Climate and atmospheric history of the past 420,000 years from the Vostok ice core, Antarctica. Nature 399:429-436

Pielou EC (1992) After the Ice Age. The University of Chicago Press, Chicago

Pires Ferreira J, Pires Ferreira E, Kaulicke P (1976) Preceramic utilization in the central Peruvian Andes. Science 194:483-490

Politis G, Gutiérrez M (1998) Gliptodontes y cazadores-recolectores de la región pampeana (Argentina). Latin Am Antiquity 9:111-134

Politis GG, Johnson E, Gutiérrez M, Hartwell WT (2003) Survival of Pleistocene Fauna: New radiocarbon dates on organic sediments from La Moderna (Pampean Region, Argentina). In: Miotti L, Salemme M, Flegenheimer N (eds) Where the south winds blow. Ancient evidence of Paleo South Americans. Center for the Study of the First Americans, pp 45-50

Politis G, Messineo PG, Kaufmann C (2004) El poblamiento temprano de las llanuras pampeanas de Argentina y Uruguay. Complutum 15:207-224

Politis G, Prado JL, Beukens RP (1995) The human impact in Pleistocene-Holocene extinctions in South America - The Pampean case. In: Johnson E (ed) Ancient peoples and landscapes. Museum of Texas Tech University, Lubbock, pp 187-205

Prado JL, Menegaz A, Tonni EP, Salemme M (1987) Los mamíferos de la fauna local Paso Otero (Pleistoceno tardío), provincia de Buenos Aires. Aspectos paleoambientales y bioestratigráficos. Ameghiniana 24:217-233

Prieto R (1996) Late Quaternary vegetational and climatic changes in the Pampa grassland of Argentina. Quat Res 45:73-88

Prevosti FJ, Soibelzon L, Prieto A, San Roman M, Morello F (2003) The southernmost record of Ursidae: The occurrence of Pararctotherium (Tremarctinae) in the Latest Pleistocene of Southern Patagonia (Chile). J Vert Paleontol 23:709-712

Pujos F, Salas R (2004) A new species of Megatherium (Mammalia: Xenarthra: Megatheriidae) from the Pleistocene of Sacaco and Tres Ventanas, Peru. Palaeontology 47:579-604

Quintana C (1996) Diversidad del roedor Microcavia (Caviomorpha, Caviidae) de América del Sur. Mastozoología Neotropical 3:63-86 
Ramírez Rozzi FV, Errico FD, Zárate M (2001) Le site paléo-indien de Piedra Museo (Patagonie). Sa contribution au débat sur le premier peuplement du continent Américain. Comptes Rendus de l'Académie des Sciences - Series IIA - Earth Planet Sci 331:311-318

Raup DM (1992) Extinction. W.W. Norton, New York

Retallack GJ (1998) Fossil soils and completeness of the rock and fossil records. In: Donovan SK, Paul CR (eds) The adequacy of the fossil record. Wiley, Chichester

Roosevelt A, Lima da Costa M, Lopes Machado C, Michab M, Mercier N, Valladas H, Feathers J, Barnett W, Imazio da Silveira M, Henderson A, Sliva J, Chernoff B, Reese D, Holman J, Toth N, Schick K (1996) Paleoindian cave dwellers in the Amazon: The peopling of the Americas. Science 272:373-384

Rossello EA, Bor-Ming J, Tsung-Kwei L, Petrocelli JL (1999) New 4,300 YR 14C age of glyptodonts at Luján river (Buenos Aires, Argentina) and its implications. II Simposio Sudamericano de Geología Isotópica, Córdoba, Argentina, pp 105-110

Roy K (2001) Pleistocene extinctions. In: Briggs, D., Crowther P (eds) Palaeobiology II. Blackwell Science, London

Sala E (2006) Top predators provide insurance against climatic change. Trends Ecol Evol 21:479-480

Sarno RJ, Franklin WL (1999) Maternal expenditure in the polygynous and monomorphic guanaco: Suckling behavior, reproductive effort, yearly variation, and influence on juvenile survival. Behav Ecol 10:41-47

Schmidt Dias A, Jacobus AL (2002) The antiquity of the peopling of southern Brazil. Curr Res Pleistocene 18:17-20

Scillato-Yané G, Carlini AA, Tonni EP, Noriega JI, (2005) Paleobiogeography of the late Pleistocene pampatheres of South America. J South Am Earth Sci 20:131-138

Scillato-Yané G, Carlini AA, Vizcaíno SF, Ortiz Jaureguizar E (1995) Los xenartros. In: Alberdi MT, Leone G, Tonni EP (eds) Evolución biológica y climática de la región pampeana durante los últimos cinco millones de años. Monografías del Museo Nacional de Cienicas Naturales 12:181-209

Sheldon PR (1998) Plus ça change - a model for stasis and evolution in different environments. Palaeogeogr Palaeocl 127:227-238

Simpson G (1980) Splendid isolation. Yale University Press, New Haven

Soibelzon LH (2002) Los Ursidae (Carnivora, Fissipedia) fósiles de la República Argentina. Aspectos sistemáticos y paleoecológicos. Ph.D. Dissertation, Universidad Nacional de La Plata

Soibelzon LH, Tonni EP, Bond M (2005) The fossil record of the South American Short-faced bears (Ursidae, Tremarctinae). J South Am Earth Sci 20:105-113

Steadman DW, Martin PS, MacPhee RDE, Jull AJ T, McDonald HG, Woods CA, Iturralde-Vinent M, Hodgins GWL (2005) Asynchronous extinction of late Quaternary sloths on continents and islands. PNAS 102:11763-11768

Steig EJ (2006) The south-north connection. Nature 444:152-153

Suárez R (2003) Paleoindian components of northern Uruguay: New data on early human occupations of the Late Pleistocene and Early Holocene. In: Miotti L, Salemme M, Flegenheimer N (eds) Where the south winds blow. Ancient evidence of Paleo South Americans Center for the Study of the First Americans, pp 29-36.

Thompson LG (2000) Ice core evidence for climate change in the Tropics: Implications for our future. Quat Sci Rev 19:19-35

Tonni EP (1990) Mamíferos del Holoceno en la Provincia de Buenos Aires. Paula-Coutiana 4:3-21

Tonni EP, Alberdi MT, Prado JL, Bargo MS, Cione AL (1992) Changes of mammal assemblages in the pampean region (Argentina) and their relation with the Plio-Pleistocene boundary. Palaeogeogr Palaeocl 95:179-194

Tonni EP, Cione AL (1997) Did the Argentine Pampean ecosystem exist in the Pleistocene? Curr Res Pleistocene 14:131-133

Tonni, E.P., Cione, A.L., (Eds.). 1999. Quaternary vertebrate palaeontology in South America.Quaternary of South America and Antarctic Peninsula 12, 1-310.

Tonni EP, Cione AL, Figini A (1999a) Predominance of arid climates indicated by mammals in the pampas of Argentina during the Late pleistocene and Holocene. Palaeogeogr Palaeocl 147:257-281
Tonni EP, Cione AL, Figini A (2001) Chronology of Holocene pedogenetic events in the Pampean area of Argentina. Curr Res Pleistocene 18:124-127

Tonni EP, Fidalgo F (1978) Consideraciones sobre los cambios climáticos durante el Pleistoceno tardío - Reciente en la Provincia de Buenos Aires. Aspectos ecológicos y zoogeográficos relacionados. Ameghiniana 15:235-253

Tonni EP, Huarte R, Carbonari JE, Figini AJ (2003) New radiocarbonic chronology for the Guerrero member of the Luján Formation (Buenos Aires, Argentina). Paleoclimatic significance. Quat Intl 109/110:45-48

Tonni EP, Nabel P, Cione AL, Etchichury M, Tófalo R, Scillato Yané GJ, San Cristóbal J, Carlini A,Vargas D (1999b) The Ensenada and Buenos Aires formations (Pleistocene) in a quarry near La Plata, Argentina. J South Am Earth Sci 12:273-291

Tonni EP, Politis G (1980) La distribución del guanaco (Mammalia, Camelidae) en la provincia de Buenos Aires durante el Pleistoceno tardío y Holoceno. Los factores climáticos como causa de su retracción. Ameghiniana 17:53-66

Tonni EP, Scillato Yané GJ (1997) Una nueva localidad con mamíferos pleistocenos en el norte de Argentina. Aspectos paleozoogeográficos. Atas do VI Congreso da Associação Brasileira do Estudos do Quaternário, Curitiba, Brazil, pp 345-348

Ubilla M, Perea D (1999) Quaternary vertebrates of Uruguay: A biostratigraphic, biogeographic and climatic overview. In: Tonni EP, Cione AL (eds) Quaternary vertebrate palaeontology in South America. Quat South Am Antarct Peninsula 12:75-91

Van Valkenburgh B (2001) The dog -eat-dog world of carnivores. A review of past and present carnivore community dynamics. In: Stanford C, Bunn HT (eds) Meat-eating and human evolution. Oxford University Press, Oxford, pp 101-121

Verzi DH, Tonni EP, Scaglia OA. San Cristóbal J (2002) The fossil record of the desert adapted South American rodent Tympanoctomys (Rodentia, Octodontidae). Paleoenvironmental and biogeographic significance. Palaeogeogr Palaeocl 179:149-158

Vialou AV (2003) Santa Elina Rockshelter, Brazil: Evidence of the coexistence of man and Glossotherium. In: Miotti L, Salemme M, Flegenheimer N (eds) Where the South Wind blows: Ancient evidence of paleo South Americans. Center for the Study of the First Americans, Portland, pp 21-28

Vivo M, Carmignotto AP (2004) Holocene vegetation change and the mammal faunas of South America and Africa. J Biogeograp 31:943-957

Waguespack NM. Surovell TA (2003) Clovis hunting strategies, or how to make out on plentiful resources. Am Antiquity 68:333-352

Ward P (1997) The call of the distant mammoth. Springer, Berlin

Webb SD, Marshall LG (1982) Historical biogeography of recent South American land mammals. Spl Publ Pymatuning Lab Ecol 6:39-52

Whitlock C, Bartlein PJ (1997) Vegetation and climate change in northwest America during the past $125 \mathrm{kyr}$. Nature 388:57-61

Wille M, Hooghiemstra H, van Geel B, Behling H, de Jong A, van der Borg K (2003) Submillennium-scale migrations of the rainforest savanna boundary in Colombia: $14 \mathrm{C}$ wiggle-matching and pollen analysis of core Las Margaritas. Palaeogeogr Palaeocl 193:201-223

Wilmers CC, Getz WM (2005) Gray wolves as climate change buffers in Yellowstone. PLOS Biology 3:571-576

Wilmers CC, Post E (2006) Predicting the influence of wolf-provided carrion on community dynamics under climate change scenarios. Global Changes, Biol 12:403-409

Wilmers CC, Post ES, Peterson RO, Vucetich JA (2006) Predator disease out-break modulates topdown, bottom-up and climatic effects on herbivore population dynamics. Ecol Lett 9:383-389

Youngblood D (2002) From Beringia to Chile in less than 250 years? Note on the rapid traversal of continents. Curr Res Pleistocene 18:66-68

Zárate M, Espinosa M, Ferrero L (1995) La Horqueta II, río Quequén Grande: Ambientes sedimentarios de la transición Pleistoceno-Holoceno. IV Jornadas Geologicas y GeofísicasBonaerenses 1:195-204

Zetti J, Tonni EP, Fidalgo F (1972) Algunos rasgos de la geología superficial en las cabeceras del Arroyo del Azul (Provincia de Buenos Aires). Etnia 15:6-11 
